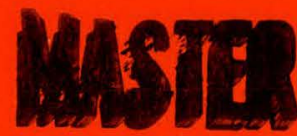

\title{
Municipal Bond Financing of Solar Energy Facilities
}

Sharon Stanton White
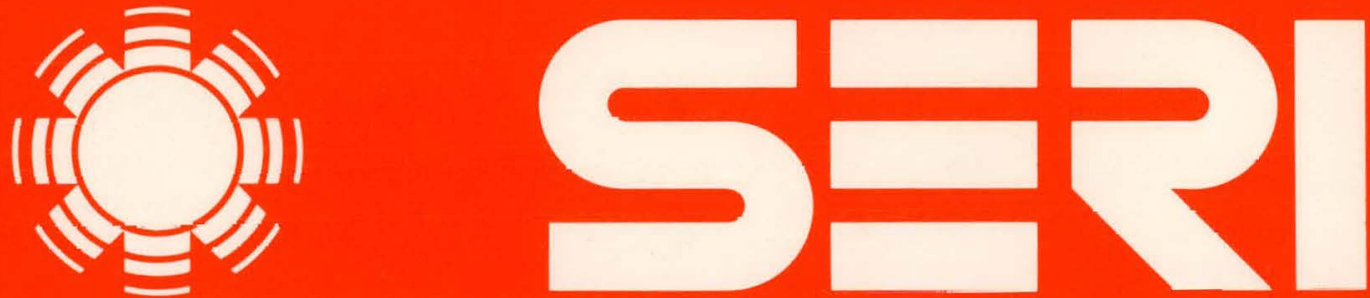

Solar Energy Research Institute A Divișion of Midwest Research Institute

1536 Cole Boulevard

Golden, Colorado 80401

Operated for the U.S. Department of Energy under Contract No. EG-77-C-01-4042

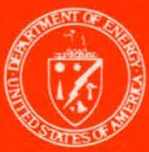




\section{DISCLAIMER}

This report was prepared as an account of work sponsored by an agency of the United States Government. Neither the United States Government nor any agency Thereof, nor any of their employees, makes any warranty, express or implied, or assumes any legal liability or responsibility for the accuracy, completeness, or usefulness of any information, apparatus, product, or process disclosed, or represents that its use would not infringe privately owned rights. Reference herein to any specific commercial product, process, or service by trade name, trademark, manufacturer, or otherwise does not necessarily constitute or imply its endorsement, recommendation, or favoring by the United States Government or any agency thereof. The views and opinions of authors expressed herein do not necessarily state or reflect those of the United States Government or any agency thereof. 


\section{DISCLAIMER}

Portions of this document may be illegible in electronic image products. Images are produced from the best available original document. 
Printed in the United States of America Available from:

National Technical Information Service.

U.S. Departinent of Commerce

5285 Port Royal Road

Springfield, VA 22161

Price:

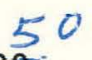

50

Microfiche $\$ 3.00$

Printed Copy $\$ 6.00$

\author{
8. $\infty$
}

\title{
NOTICE
}

This report was prepared as an account of work sponsored by the United States Government. Neither the United States nor the United States Department of Energy, nor any of their employees, nor any of their contractors, subcontractors, or their employees, makes any warranty, express or implied, or assumes any legal liability or responsibility for the accuracy, completeness or usefulness of any information, apparatus, product or process disclosed, or represents that its use would not infringe privately owned rights. 
MUNICIPAL BOND FINANCING OF SOLAR ENERGY FACILITIES

SHARON STANTON W!HITE

DECEMBER 1979

PREPARED UNDER TASK No. 6721.40

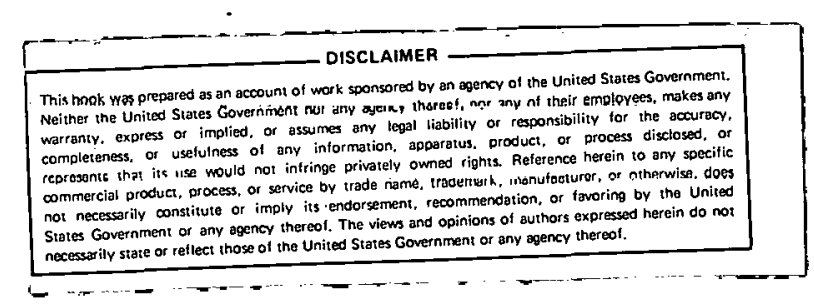

Solar Energy Research Institute

1536 Cole Boulevard

Golden, Colorado 80401

A Division of Midwest Research Institute

Prepared for the

U.S. Department of Energy

Contract No. EG $\cdot 77 \cdot \mathrm{C} \cdot 01 \cdot 4042$ 


\section{THIS PAGE}

\section{WAS INTENTIONALLY LEFT BLANK}




\section{FOREWORD}

This Legal Reconnaissance Paper on Municipal Bond Financing of Solar Energy Facilities was prepared by the Solar Energy Research Institute (SERI) to fulfill, in part, SERI's solar information dissemination function. This paper is part of the Market Development Branch Law Program, which in turn is a part of the overall program of the Commercialization Division.

This is the fourth of five Legal Reconnaissance Papers sponsored by the SERI Law Program. The other four address (1) legal issues surrounding the commercialization of OTEC, (2) legal issues pertaining to the commercialization of WECS, (3) regulated utilities and solar energy, and (4) legal issues raised by the commercialization of solar heating and cooling (SHAC) devices. These five studies are meant to broadly survey the legal questions that are raised by either a specific solar technology (i.e., OTEC, SHAC, and WECS) or a potential barrier or incentive to the general commercialization of solar technologies (i.e., utilities and municipal bonds). It is hoped that these reconnaissance papers will be springboards for further, more detailed studies of some aspect of the general topic covered.

Sharon Stanton White is a partner in the San Francisco law firm of Jones, Hall, Hill, and White, where she practices in the area of municipal bonds.

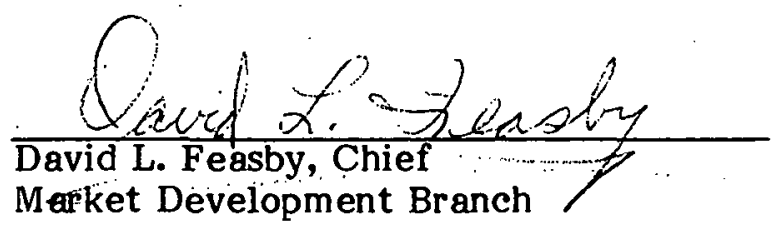

Approved for:

SOLAR ENERGY RESEARCH INSTITUTE

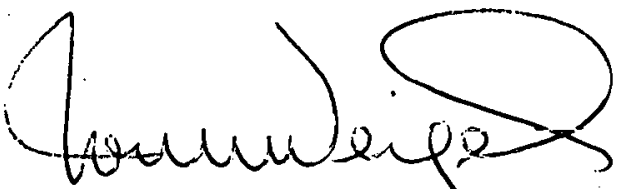

Jon M. Veigel, Assistant Director

Commercializ ation Division 


\section{THIS PAGE \\ WAS INTENTIONALLY \\ LEFT BLANK}




\section{SUMMARY}

This report examines the application of the laws of municipal bond financing to solar facilities and is based upon the assumption that the solar facilities proposed to be financed are both technically feasible and economically beneficial.

The introduction outlines the type of facilities under consideration. These facility types are more comprehensive than is generally recognized by persons not expert in the field of solar energy applications. Included as solar facilities are those involving biomass conversion systems, wind-power installations, ocean thermal energy conversion systems, residential and commercial solar heating and cooling systems, agricultural and industrial process heat systems, solar thermal conversion systems, photovoltaic systems, and solar power satellites.

Section 2.0 discusses the general legal principles of municipal securities financing. This section, in turn, is divided into three segments. The first segment discusses general constitutional and statutory principles applicable to all forms of municipal bonds; the second segment discusses five major types of municipal bonds, their nature, and their inherent limitations; and the third segment discusses federal tax limitations applicable to the issuance of municipal bonds. Among general legal principles, the power to issue bonds is the power to incur debt; in order to issue bonds, the municipality must find both that the facilities to be financed satisfy a public purpose, and that the bonds to be issued are expressly authorized by state statute or constitutional provision. Section 2.0 notes that many state constitutions and statutes contain certain limitations which affect the power of political subdivisions to issue bonds and discusses the application of such limitations (including prohibitions against gif ts and loans, capital improvement limitations, and tax limitations) to the issuance of municipal bonds. The effect of recent decisions applying antitrust liability to municipal corporations is also discussed.

Section 2.0 then turns to five specific types of municipal bonds and explains the nature of such bonds. Included in the consideration are general obligation bonds (i.e., bonds backed by the full faith and credit, as well as the taxing power of the issuing entity), revenue bonds (i.e., bonds payable from a specific source of funds other than tax revenues of the locality), assessment bonds (i.e., bonds payable from specific charges called assessments, levied upon properties specifically benefited by the facilities to be financed) and two unique types of revenue bonds (industrial development bonds and housing mortgage bonds).

Finally, Section 2.0 discusses the application of Section 103 of the Internal Revenue Code of 1954, as amended, to the issuance of municipal bonds for solar facility financing. The importance of this portion of the study cannot be underestimated, for if the interest paid on the bonds issued is not tax exempt the advantage of issuance of exempt bonds (namely, the low interest rate which results from tax-exempt interest financing) is lost.

Municipal bonds cannot be issued without express statutory authorization. Section 3.0 examines five bond laws of five representative states (California, Florida, Illinois, New Mexico, and New York) and discusses whether the eight types of solar facilities under consideration could be financed under such law.

Section 4.0. illustrates the application of the general legal principle discussed in Sections 1.0 and 2.0. It sets forth three hypothetical situations (the first relating to the financing of active solar heating systems, the second relating to the financing of a biomass conversion system, and the third relating to the financing of a wind-power 
facility for an industrial plant), and discusses common legal issues to be confronted by city officials in proposing such financing. These issues will be raised in most financings, but the purpose of Section 4.0 is to examine the common context in which they are raised.

The report concludes that if it can be shown that the purpose of the solar facilities to be financed is to benefit the public, all legal obstacles to the use of municipal financing of solar facilities can be substantially overcome. The ultimate use of such financing, however, will depend on the existence of technical and economic feasibility of the systems involved. 
TABLE OF CONTENTS

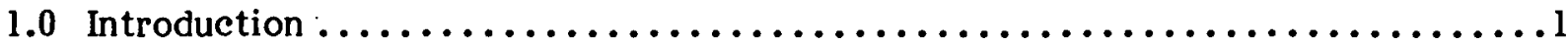

2.0 General Legal Principles of Municipal Securities Financing .............. 5

2.1 Bond Issuance: State and Federal Legal Framework ...............5

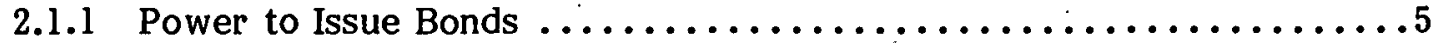

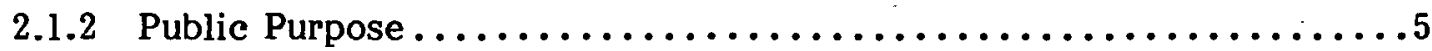

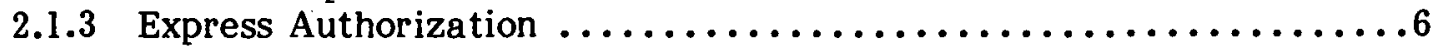

2.1.4 Limitations Upon Bond Issuance .....................

2.1.5 Prohibition Against Gif ts and Loans....................

2.1.6 Limitations to Capital Improvements $\ldots \ldots \ldots \ldots \ldots \ldots \ldots \ldots \ldots \ldots . \ldots \ldots$

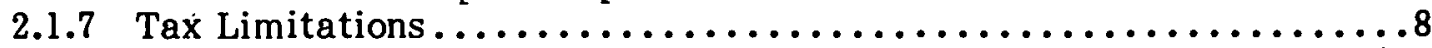

2.1.8 Project Limitations: Antitrust Liability $\ldots \ldots \ldots \ldots \ldots \ldots \ldots \ldots \ldots 9$

2.2 Basic Bond Forms: Nature and Inherent Limitations $\ldots \ldots \ldots \ldots \ldots \ldots \ldots$

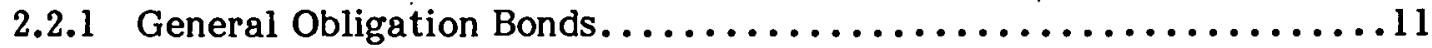

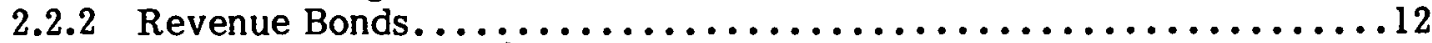

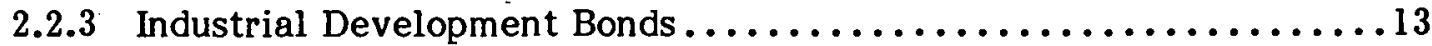

2.2.4 Mortgage-Backed Bonds ............................. 14

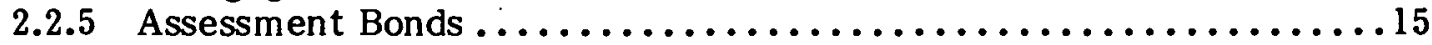

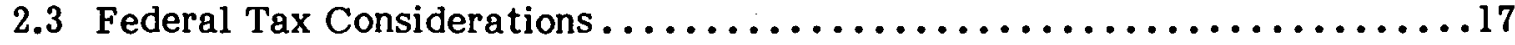

2.3.1 Solar Energy Bonds as Industrial Development Bonds . . . . . . . . 18

2.3.2 Qualification of Solar Energy Bonds Under Special

Activities or Small Issue Exemptions .................23

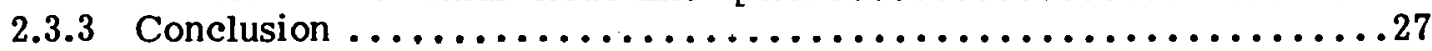

3.0 Specific Bond Laws $\ldots \ldots \ldots \ldots \ldots \ldots \ldots \ldots \ldots \ldots \ldots \ldots \ldots \ldots \ldots \ldots \ldots \ldots$

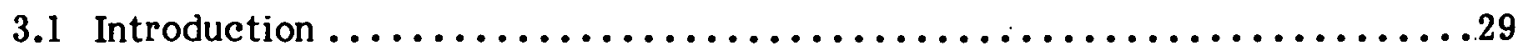

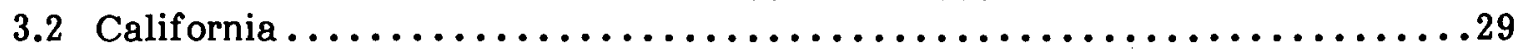

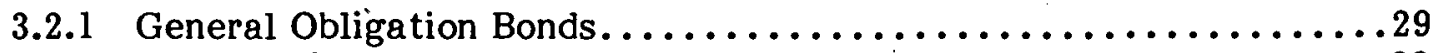

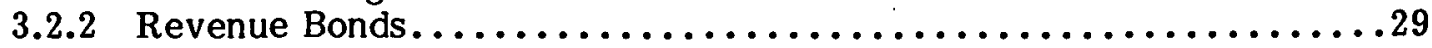

3.2 .3 Industrial Development Bonde . . . . . . . . . . . . . . . . . 30

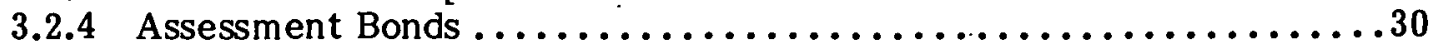

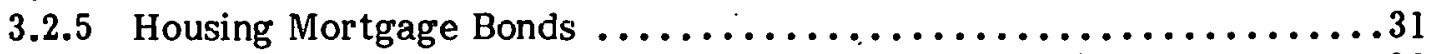

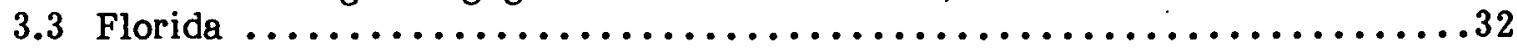

3.3.1 General Obligation Bonds.............................. 32

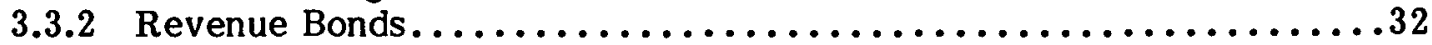

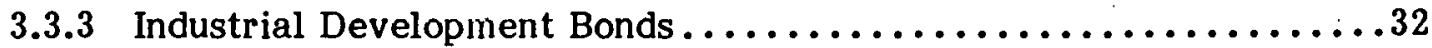

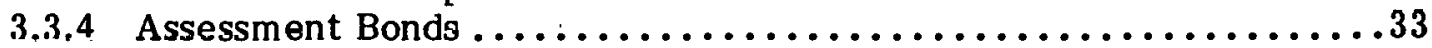

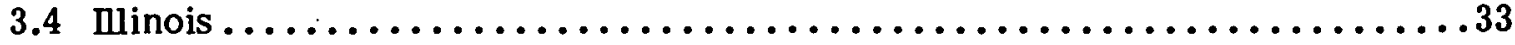

3.4.1 General Obligation Bonds............................

3.4 .2 Revenue Bonds.................................... 34

3.4.3 Industrial Development Bonds......................... 35

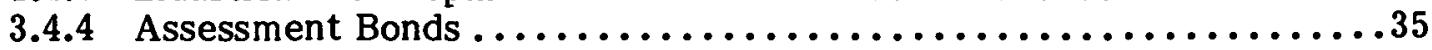

3.4.5 Housing Mortgage Bonds ..............................

3.5 New Mexico .............................................. 


\section{TABLE OP CONTENTS (concluded)}

\section{Page}

3.5.1 General Obligation Bonds.............................

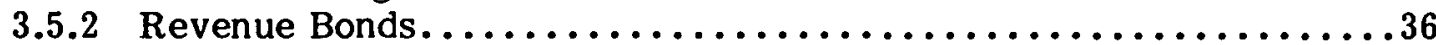

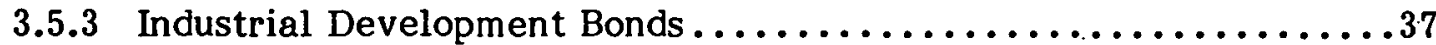

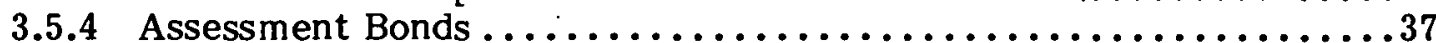

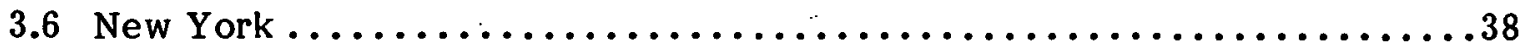

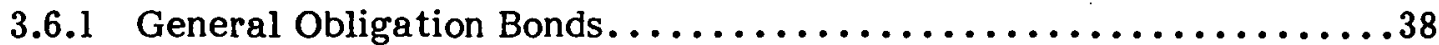

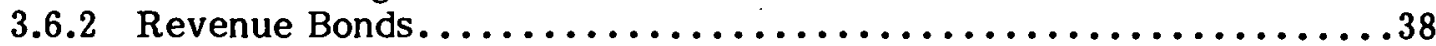

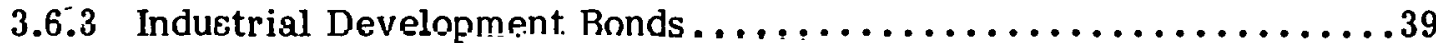

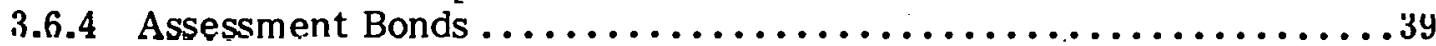

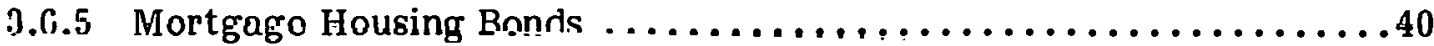

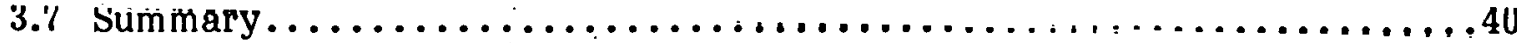

4.0 Hypothelleul Cúsés $\ldots \ldots \ldots \ldots \ldots \ldots \ldots \ldots \ldots \ldots \ldots \ldots \ldots \ldots \ldots \ldots \ldots \ldots \ldots \ldots \ldots$

4.1 Hypothetical Case Number 1: Active Solar Heating Systems . . . . . . . . 47

4.1.1 Public or Corporate Purpose ....................... 48

4.1.2 Questions of Property Rights ....................... 48

4.1 .3 Selection and Structuring of Bond Issue.................. 49

4.1.4 Acquisition, Installation, and Maintenance of Equipment ........50

4.1.5 Coordination with Competing Utilities $\ldots \ldots \ldots \ldots \ldots \ldots \ldots \ldots \ldots 1$

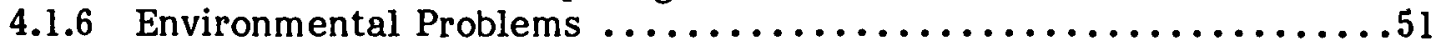

4.2 Hypothetical Case Number 2: Biomass Conversion System ............

4.2.1 Selection of Bond Issue..............................

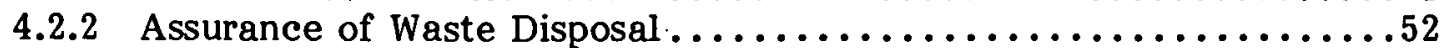

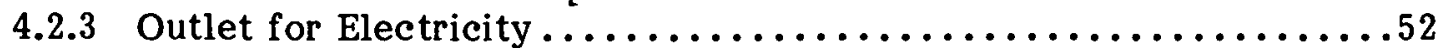

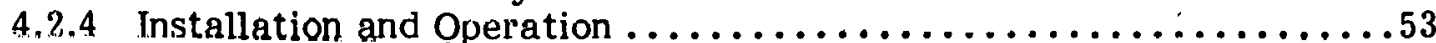

4.2 .5 T'ax Problems .................................. . . . . . .

4.3 Hypothetical Case Number 3: Wind Power for Industrial Plant .........53

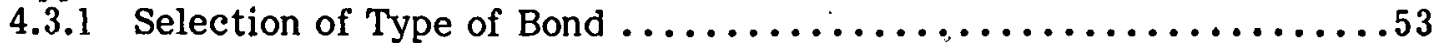

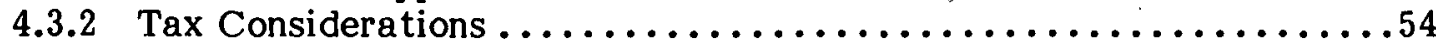

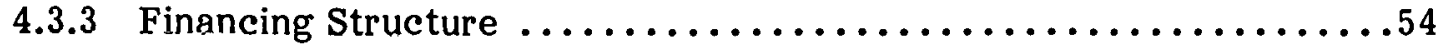

4.3.4 Public Opinion and Environmental Concerns............... 55

4.4 Hypothetical Case Conclusions ..........................55

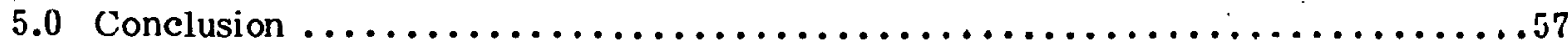

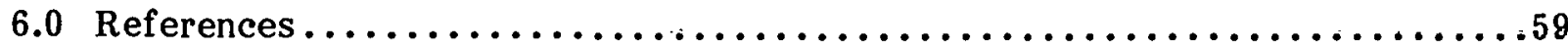




\section{LIST OF FIGURES AND TABLES}

Table

1-1 Summary of Legal Considerations in Solar

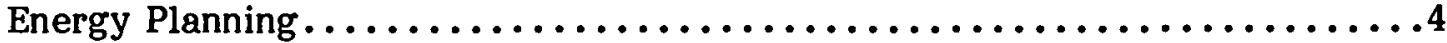

2-1 Summary of Tax Considerations Relating to

Solar Energy ..................................... 28

3-1 Sum mary of Statutory Bond Authorities

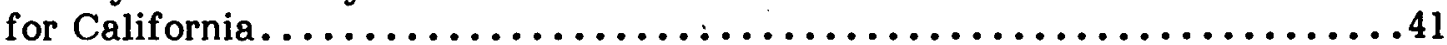

3-2 Summary of Statutory Bond Authorities for Florida

3-3 Sum mary of Statutory Bond Authorities for Illinois.

3-4 Summary of Statutory Bond Authorities for New Mexico.

3-5 Summary of Statutory Bond Authorities

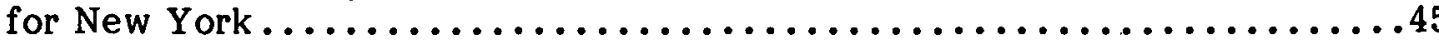




\section{SECTION 1.0}

\section{INTRODUCTION}

The long-term outlook for the future prices and supplies of our traditional energy sources has forced this country to begin to consider other potential energy sources. Solar energy is receiving major attention as one of the potential energy supplies, both for near-term and long-term use.

Until now, assistance to municipalities for the use of solar energy has been primarily indirect, through the use of zoning, property, and land-use powers. Direct assistance, however, through local government financing, may increasingly become the focus of inquiry.

The purpose of this report is to explore the legal issues surrounding application of municipal bond financing to the financing of solar energy facilities. Section 2.0 discusses the legal framework of municipal bond financing and constitutes a summary of general principles related to municipal borrowing. Section 3.0 examines five types of bond laws in five representative states and discusses the possible application of such bond laws to solar facility financing. Section 4.0 sets forth several hypothetical situations and explores particular problems and procedural difficulties which may be faced in general sol ar financings.

\section{A Solar Facility}

A solar facility is any capital improvement that converts energy from the sun to an energy form that can be utilized by residential, commercial, and industrial consumers. Such conversion may be direct (i.e., the conversion of solar energy to heat for purposes of space heating or to electricity in photovoltaic cells) or indirect (i.e., the conversion of solar energy to useful energy forms from sources such as wind or living matter (biom ass), which are indirectly energized by the sun). Commonly recognized fossil fuels such as petroleum, natural gas, and coal are excluded from this definition.

Based upon this broad definition, there are at least eight distinct types of sol ar facilities which can be employed for residential, commercial, transportational, or industrial usage. These eight types of facilitics arc dçcribed briefly in the following paragraphs.

\section{Biom ass Conversion Systems}

Biomass is any material derived from living matter, and is therefore recognized as a natural form of solar energy. Wood, for example, is biom ass. A biomass conversion system is any facility used to convert biomass to usable energy. A fireplace would be an example of a biomass conversion system; i.e., it is a facility used to combust wood to produce heat for the homc.

Biomass conversion systems utilize three principle biomass sources: (1) wastes (municipal wastes such as sewage, garbage, and newspaper), (2) residues (plant remains left over from forestry or agricultural operations), and (3) fuel crops (crops that are specifically cultivated to be used as fuel sources). These biomass sources are either converted directly to heat or are converted to intermediate fuels by two main bioconversion techniques known as thermochemical conversion and biological conversion. 
Thermochemical conversion utilizes heat to produce chemical reactions in biomass sources. Examples of thermochemical conversion systems include gasifiers (f acilities that generate a gas from organic residue, which can be substituted for gas and oil in existing equipment), and pyrolizers (facilities that, through high temperature heating of biomass without oxygen, produce an oil, gases, or both).

Biological conversion utilizes microorganisms which produce several materials. Examples of biological conversion systems include anaerobic digesters (facilities that, through controlled microbial decomposition of organic matter in the absence of air, produce a medium-Btu gas that can be burned directly or upgraded) and fermentation systems (facilities that, through a fermentation of agricultural products, produce alcohols).

\section{Wind-Power Installations}

Wind is the result of solar radiation conversion by the earth's atmosphere into kinetic energy, and is therefore recognized as a form of solar energy. A wind-power installation is any facility that is used to convert wind power to usable energy. A windmill and wind generator, for example, are facilities that harness wind to operate pumping mechanisms and to generate electricty. Wind-power installations of interest in this paper include wind turbines ranging in size from units serving single residences to plants of several megawatt (MW) capacity.

\section{Ocean Energy Conversion Systems}

Oceans constitute a repository of solar energy, both in the form of kinetic energy stored in waves and tidal currents and in the form of temperature differentials. Any system that converts solar energy in the ocean into usable energy constitutes an ocean energy facility.

Technological endeavors in the field of ocean therm al energy conversion systems include the development of facilities that use sun-heated ocean surf ace water to vaporize a fluid such as propane or ammonia. The vapor then drives a turbine to produce electricity. Other ocean energy facilities harness ocean waves and the tides to generate electricity.

\section{Residential and Commercial Solar Heating and Cooling Systems}

These systems are perhaps the most commonly recognized of the solar facilities. They include both active systems and passive systems, and are designed for the heating and cooling of space and the heating of domestic water. An active system is generally comprised of a collector facility (e.g., a roof absorber plate that transfers heat from the sun to a fluid); a system of ducts, vents, and pumps or fans to distribute the collected heat to the place or places in the building where the heat is needed; and a storage facility such as a hot water reservoir, in which the collected heat is stored when not needed. In a passive system, the end result (provision of heat) is the same. The building itself, however, acts as the collector and storage unit. Architectural design, thermal mass, and structural insulation are taken into account in the development of a passive solar heating and cooling system. References throughout this paper to heating and cooling systems do not include heat obtained from solar-generated electricity such as photovoltaics. These are considered throughout as a separate type of solar system. 


\section{Agricultural and Industrial Process Heat Systems}

This category relates to systems comparable to the active system described previously. The active systems are designed for residential space and water heating, while the end result of agricultural and industrial process heat systems is the production of heat for agricultural and industrial uses. The systems are comprised of collectors, distribution ducts and $f$ ans, and storage facilities. The heat that is collected, distributed, and stored may be used for such processes as heating clean-up water, cooking, curing, and air drying. The production of high temperature steam (through technology including fully tracking parabolic dishes or linear focusing collectors) for varied heavy industrial process heat dem ands is also included in this category.

\section{Solar Thermal Conversion Systems}

This term refers to solar facilities used to convert solar thermal power to electricity. This category includes "power towers" (collector systems consisting of a large tower surrounded by a field of tracking mirrors that concentrate the sun's rays onto a boiler in the tower), and "distributed collector systems" (e.g., a field of mirrored parabolic troughs, dishes, or lenses that concentrate the sun's rays onto a line or point receiver). In all cases, the facilities use solar collectors to generate steam or a high temperature gas or fluid that in turn drives a turbine and generator to produce electricity. In some applications, the waste heat from this electrical generation process can be utilized economically; the resultant system is then termed a "solar total energy" facility.

\section{Photovoltaic Systems}

As in solar thermal conversion systems, the end purpose of photovoltaic systems is the generation of electricity. Photovoltaic cells are solid-state devices for the direct production of electricity from sunlight. Solar cells are ordinarily placed in a sealed glass unit that is positioned into a rigid frame and arranged at a site to form a field meeting specific electrical requirements. A storage system (usually a battery system) ordinarily accompanies the solar cells. A converter is also required to change the direct electrical current produced by the cells to alternating electrical current and to maintain a constant voltage output. As in the preceding segment, sol ar total energy applications are also mssible.

\section{Solar Power Satellite}

A solar power satellite is generally described as a system of photovoltaic panels that orbits the Earth. The generated direct current is converted and transmitted to Earth through microwaves by a sharply focused antenna. The microwave energy is received by a corresponding antenna located on Earth and is processed for further use by electrical utilities. The arca served by electricily from the satellite can range from a large city to a group of states.

The preceding information provides a framework for Table 1-1 and its conclusions. Obviously, the technology varies immensely between systems. Commonalities of the facilities should be noted, as Table 1-1 sets forth relevant points that are of interest in examining the law of munioipal financing as applied to sol ar facilities. 
Table 1-1. SUMMARY OF LEGAL CONSIDERATIONS IN SOLAR ENERGY FINANCING

\begin{tabular}{|c|c|c|c|c|c|}
\hline $\begin{array}{l}\text { Type of } \\
\text { Facility }\end{array}$ & $\begin{array}{l}\text { Produces } \\
\text { Electricity }\end{array}$ & $\begin{array}{c}\text { May Be } \\
\text { Located in } \\
\text { City Limits }\end{array}$ & $\begin{array}{l}\text { May Serve } \\
\text { an Area of } \\
\text { Structures }\end{array}$ & $\begin{array}{l}\text { Produces } \\
\text { Gas }\end{array}$ & $\begin{array}{l}\text { "Treats" } \\
\text { Water }\end{array}$ \\
\hline Biomass & Yes & Yes & Yes & Yes & No \\
\hline Wind Power & Yes & Yes & Yes & No & No \\
\hline Ocean & Yes & No & No & No & Yes \\
\hline & & & & & \\
\hline Commercial & & & & & \\
\hline & & & & & \\
\hline Systems & No & Yes & No & No & Yes \\
\hline \multicolumn{6}{|l|}{ Súlä Tliel'mal } \\
\hline Conversinn & Yes & Yes & Yes & No & Yes \\
\hline Photovoltaics & Yes & Yes & Yes & Ño & No \\
\hline Satellite & Yes & No & Yes & No & No \\
\hline
\end{tabular}

This report is directed solely to the legal considerations applicable to the use of taxexempt bonds for financing sol ar facilities. However, legal considerations constitute the last, and perhaps the least, considerations in solar facility financing. Of much greater importance is the technological and economic feasibility of the solar facilities proposed to be financed. Simply because the form of financing is or is not legal as applied to solar facilities does not make it appropriate or beneficial. The findings of economic benefit and technological feasibility are a precedent condition to the financing. 


\section{SECTION 2.0}

\section{GENERAL LEGAL PRINCIPLES OF MUNICIPAL SECURITIES FINANCING}

The purpose of this section is to set forth general powers and limitations associated with the authorization, issuance, and sale of municipal bonds. The application of municipal financing to solar facilities cannot be examined without a basic knowledge of such powers and limitations.

\subsection{BOND ISSUANCE: STATE AND FEDERAL LEGAL FRAMEWORK}

\subsubsection{Power to Issue Bonds}

The power to issue bonds refers to the power to incur indebtedness. Bonds are nothing more than an evidence of indebtedness validly and lawfully incurred for proper purpose. They may be issued for a public purpose, provided that the purpose for which they are issued is expressly authorized or necessarily implied in the law.

\subsubsection{Public Purpose}

It is axiomatic in the law of local government that public power must be exercised for a public rather than private purpose, and that public funds may be expended only for a public purpose [1]. This is true whether the funds are borrowed, through incurring bonded indebtedness or otherwise, or whether the funds are on hand through accumulation of tax revenues, payments for municipal services, or otherwise. The concept of public purpose is not subject to exact definition; each case must be determined upon its own facts [2] Based on case law, that which fulfills a public purpose is not limited to that which satisfies a public need [3]. The overriding test is whether the proposed action or expenditure by local government will benefit the community [4], or to use the phraseology of the Preamble to the United States Constitution, whether the proposed action or expenditure will "promote the general welf are."

There is, in fact, not a prohibition per se against governmental expenditures for luxuries; if the public is benefited or if the general welfare is enhanced. Thus, public expenditures for television [5], swimming pools, public monuments, and a city marching band have been upheld, though considered by some persons to be luxuries. Artificial lighting by gas or electricity has been called a luxury by the courts and has been found not to be absolutely necessary but necessary for comfortable living. In sum, it has been stated that the public purpose test "has for its objective the promotion of public health, safety, morals, security, prosperity, contentment, and the general welfare of the community" [6].

The public purpose does not require that only the public is benefited; i.e., incidental private benefit will not invalidate the expenditure of public funds for a use that is otherwise primarily of public benefit [7]. Thus, incidental private benefit is recognized by downtown store owners in the construction of parking facilities, by individual water users in the installation of a water system, by specifically located residences and commercial enterprises in the paving of a particular street, and by loans to veterans. Such projects satisfy a fundamental public purpose, notwithstanding their incidental benefit to identi- 
fied private persons. Thus, it has been stated that it is not essential that the entire community, or even a considerable portion of it, directly enjoy or participate in an improvement to make it a public one.

In two particular areas of predominant bond activity-industrial development and housing-the individual benefit to private persons is clear. The public purpose behind bond issues for such activities has been substantially recognized. In a typical bond issue for industrial development, a city or other public entity issues bonds, and with the proceeds constructs and leases or sells (or lends the money to finance) a factory or other industrial enterprise to a private profit-making company. The company utilizes the factory for manufacturing or other business purposes, and pays the city (through leaserentals or purchase payments) the amount necessary to make debt service payments on the bonds. Notwithstanding the private benefit to the industry from the expenditure of bond proceeds, the public beriefit and overriding public purpose can be found in the creation of local jobs and in the stimulation of the local economy [8].

Housing bonds afford the same incidental private benefit to Indlvidual humeuwitis. With recent bond issues, for example, a city or other public entity issues bonds and uses the proceeds to make or purchase private mortgages representing lours to private homeowners (ordinarily of low or moderate income), for the purpose of acquiring or renovating a home. The homeowner loan payments are used to pay debt service on the city's (or other entity's) housing bonds. Once again, the private benefit to the homeowner is clear. The public purpose is fulfilled since the public as a whole is benefited by the provision of decent, safe, and sanitary housing to those who would be unable to provide it for themselves. The potential detriments of high crime, ill health, and unsanitary living conditions are prevented [9]. Consistent examples of clear private benefit but overriding public benefit can also be found in the areas of pollution control bonds and redevelopment bonds.

The courts recognize that the public purpose doctrine is not static but changes to meet new developments and conditions of time [10]; what was not a public purpose a few decades ago may be so now. One court stated in 1914, in analyzing the public provision of lighting and heat through electricity:

Conditions as to lighting met with ... changes. Candles, lamps, gas and electricity have followed each other in due course of time . . . . If then, science had advanced so far that the heating as well as the lighting of houses by electricity were now a practicable method, there wuuld seeri no doubt that this also would fall within the realm of public purposes. [11]

Thus, if a proposed undertaking is scientifically practicable and benefits the public, the courts will not be reluctant to find that the public purpose doctrine is fulfilled.

The public purpose doctrine is an ever-evolving concept. There should be liltle difficulty in supporting the conclusion that most municipal bond financings of solar facilities, benefiting the public, satisfy a public purpose.

\subsubsection{Express Authorization}

As noted previously, it is not sufficient that the purpose for which a city proposes to issue bonds be public in nature. There also must be a purpose for which the issuance of bonds has been authorized; i.e., the power to issue the bonds must be expressly granted or necessarily implied in order to carry out such powers. 
It has been held that the power of a city to direct a sum to be raised for a particular purpose (i.e., by a levy of taxes) does not encompass the power to borrow the sum for such purposes [12], that the power to raise money in any one year by borrowing does not carry power to raise money by an issue of negotiable bonds extending over a period of years [13], and that the power of a city to pay for a purchase of an electric plant from revenues generated by the plant does not encompass the power to enter into an obligation for payment that might ultimately result in a liability upon taxpayers [14].

Similarly, with respect to the purpose of the borrowing, it has been held that the authority to issue bonds for public buildings does not encompass the authority to issue bonds for garbage plants [15]; that the authority to issue bonds for the establishment and alteration of water courses and bridging of the same does not encompass the authority to issue bonds for docks and wharves; and that the authority to issue bonds for wharves does not encompass the authority to issue bonds to repair such facilities [16]. On the other hand, authority to issue bonds for municipal purpose appears to encompass the authority to issue bonds for any improvement, facility, or enterprise that meets the public purpose test as applied to the municipality.

In states where home-rule cities are recognized, in the area of municipal affairs or corporate purposes, the cities have all powers subject only to limitations contained in the state constitution or in the municipal charter [17]. Thus, the governing body may expressly authorize itself through legislative action to issue bonds for a particular purpose, if such purpose constitutes a municipal affair, even though state statutes are silent on the question of whether bonds of the type proposed may be issued for the purpose sought. In a limited number of cases, the home-rule municipality may successfully issue bonds even in the face of a conflicting state statute [18]. Home-rule powers have been used for innovative financing and are increasingly attractive to municipal bond issuers.

The concept of "municipal affair," like the concept of public purpose, is an evolving concept. As is true with the public purpose doctrine, courts refuse to define the term municipal affairs generally [19], but permit each case to be decided upon its own facts and particular circumstances [20]. They note that the municipal affairs concept is not fixed but fluctuates with every change in conditions upon which it is to operate [21]. In a given case of conflict between a state affair and a municipal affair, the question appears to be whether the interest of the state or that of the municipality is paramount [22]. Again, the concept of municipal affairs will vary between states, depending in part upon the phraseology of the home-rule provisions of the state constitution [23]. The procedure and manner of issuing municipal bonds are in some states considered municipal affairs; the reverse is true in other states [24]. However, in most states, the provision of light, heat, power, and water for the inhabitants of a municipality is ordinarily considered a proprietary matter of the city and a municipal affair [25]. Since solar facilities are ordinarily directed toward the provision of light, heat, or power, it is probable that the installation of facilities serving all or a portion of a municipality would be considered by the courts to constitute a municipal affair.

\subsubsection{Limitations Upon Bond Issuance}

Once it is determined that a municipality has the power to issue bonds for a particular purpose, the applicable limitations upon such power must be examined. Some of the limitations are inherent in the nature of the bond proposed to be issued and will be discussed in Segment 2.2. Other limitations, however, relate to all bond issues and are of common interest, either because of the frequency of their inclusion in state constitutions or because of the frequency of their concern to municipalities in specific undertakings. 


\subsubsection{Prohibition Against Gif ts and Loans}

Second only to debt limitations, prohibitions against gif ts and loans of credit to individuals and private corporations are the most frequently noted state constitutional limitations affecting municipal bond issuance. The prohibitions are, in effect, the obverse of the power to issue bonds for a public purpose. If the primary purpose of the bond issue is to give a gift or make a loan to a private corporation, then the bonds are not being issued for a public purpose. On the other hand, it is generally recognized that even though the result of a bond issued is a gift or loan to a private person, if such gift or loan (i.e., the bond issue) satisfies a public purpose, then the gift or loan is not within the constitutional prohibition. Thus, the use of bond proceeds to enable a private corporation to install pollution control equipment in its manuf acturing enterprise would not be a prohibited gift or loan of credit, because the public purpose is satisfied.

The prohibitions originally were aimed at confining the use of public funds and public credit to public purposes, and undoubtedly stemmed from early municipal involvement in railroad aid bonds. In those cases where the railroad was poorly managed and failed, the burden of the debt often fell upon the taxpayers of the community-with the result that taxes to pay a debt incurred for a particular purpose continued long af ter the purpose ceased to exist.

\subsubsection{Limitations to Capital Improvements}

The constitutions of some states limit the issuance of municipal bonds to capital improvements. Therefore, the use of bonds for maintenance purposes, working capital, etc., is prohibited in such states. The definition of capital improvement is unsettled in such states, but the purpose of the prohibition appears to be similar to one of the purposes behind the prohibition against gif ts or loans of credit to private individuals and corporations; i.e., the prevention of requiring future taxpayers to pay for something nonexistent. The effects of providing maintenance expenses and working capital may dissipate long before the bonds are paid, and the burden of bond payment may outweigh the benefit of enjoyment of the service or facility.

\subsubsection{Tax Limitations}

'The responsibility for levying taxes for a general obligation debt is commonly recognized, and the passage of a law limiting tax levies cannot lessen such responsibility without unconstitutionally impairing the contract of the city with the bondholder. However, municipal authorities in some states have become increasingly concerned about the effect of state constitutional initiatives that impose tax limitations upon their ability to issue bonds for particular purposes.

A pure limitation upon tax levies is not a limitation upon bond issuance [26]. On the other hand, the exact wording of the constitutional tax initiative (or state statute) may result in a limitation upon bond issuance, without having such result as its stated intent.

Article XIIIA (Proposition 13) was recently added to the California constitution by the voters. It establishes a limitation upon ad valorem taxes on real property (at $1 \%$ of the full cash value of property), but also provides that "no new ad valorem taxes on property" may be imposed. Also, cities (by a two-thirds vote of the qualified electors) may impose 
special taxes, but "such taxes may not include ad valorem taxes on real property." It is arguable, on the face of the provision, that general obligation bonds secured by ad valorem taxes could not be issued af ter the effective date of the initiative if payment of such bonds required a tax rate in excess of the $1 \%$ cap on property taxes imposed by the initiative.

Of even greater concern to municipalities, is the effect of Proposition 13 on their ability to pay outstanding bond issues. The initiative provides that its limitation "shall not apply to ad valorem taxes or special assessments to pay the interest and redemption charges on any indebtedness approved by the voters prior to the time the initiative becomes effective." In California, certain bond issues do not require voter approval. These include special assessment bonds, lease revenue bonds, and redevelopment agency tax allocation bonds. Many such bond issues are now outstanding. The California Supreme Court, when confronted with the argument that the initiative constituted an unconstitutional impair ment of contract, responded, "Nothing on the face of Article XIIIA requires local agencies to default either in meeting their preexisting contracts or in liquidating their outstanding bonds." The matter will undoubtedly be pursued, but is noted here as a tax limitation provision that ultimately may constitute a limitation upon bonds.

Tax limitation initiatives have been adopted or are now pending in many states. The wording of such initiatives varies, and it is incumbent upon each municipality to examine the specific wording of the new tax initiatives to determine their applicability to future bond issuance. Their ultimate effect as a whole on the power to incur debt, as well as on the obligation to pay preexisting debt, is yet to be seen and is beyond the scope of this report.

\subsubsection{Project Limitations: Antitrust Liability}

The limitations discussed in the preceding segment relate primarily to limitations on bond issuance. However, the power to initially undertake the project defines the power to issue bonds for the project. Similarly, limitations on the project may affect the nature and validity of the bond issuance. Most of these limitations, because of their broad applicability, are unsuitable for elaboration in this paper. Such limitations include environmental laws, relocation requirements, public bidding and construction specification restrictions, open meeting laws, and conflict of interest prohibitions.

A major project limitulion of recent concern is the application of federal antitrust law to municipalities operating public utilities. This is important because electric power production may be the end result of many of the solar energy technologies. This limitation, resulting from the recent holding of the United States Supreme Court in City of Lafayette v. Louisiana Power and Light Co. [27], represents a significant departure from preexisting law. Until the Louisiana Power and Light case, it was generally recognized that the Sherman Antitrust Act did not apply to state and local governments. The United States Supreme Court in Parker v. Brown, first enunciated the doctrine that the act did not "restrain a state or its officers or agents from activities directed by its legislature" [28]. The Court nuled that both the history and the purpose of the Act were to prohibit monopolies created and maintained by individuals and private corporations. For the purposes of the Parker analysis, since a municipality acted only through the delegated authority of the state, a municipality was treated as if it were the state itself. The courts were generally united on the proposition that a municipally owned and operated public utility was entitled to antitrust immunity. 
However, this unity was shattered with the Louisiana Power and Light case. The case involved two Louisiana cities that owned and operated electric utility systems both within and beyond their own city limits. The cities brought action against the major privately owned power and light utility company, alleging that the company committed various antitrust offenses that injured the cities in the operation of their electric utility systems. The company counterclaimed, seeking damages and injunctive relief for various antitrust offenses that the cites had allegedly committed and that injured the company in its business and property. The cities moved to dismiss the counterclaim on the grounds that as cities and subdivisions of the state of Louisiana, the Parker state action doctrine

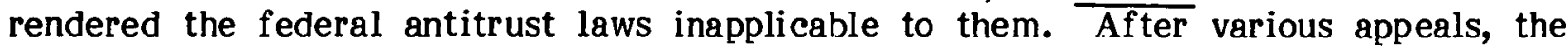
United States Supreme Court agreed to hear the case.

The United States Supreme Court, after extensive analysis of the Sherman Act and the Parker doctrine, held that the Sherman Act did not expressly exclude municipalities from its coverage and that if such an exclusion were implied "a serious chink in the armor of antitrust protection would be introduced at odds with the comprehensive national policy Congress established" [29]. The Court also stated that the Parker case limited the exemption to "official action directed by the State" and noted that such limitation arose from our dual system of government with sovereign states. However, "(c)ities are not themselves sovereign; they do not receive all the federal deference of the State that creates them." The Court concluded "that the Parker doctrine exempts only anticompetitive conduct engaged in as an act of government by the state as sovereign, or by its subdivisions, pursuant to state policy to displace competition with regulation or monopoly public service" [30]. Thus, when the state has not directed or authorized an anticompetitive practice, the subdivisions of the state must obey the antitrust laws.

The meaning of "directed" or "authorized" anticompetitive practice is open to dispute. The Louisiana opinion represented the plurality of the justices rather than the majority. Nevertherless, it can no longer be assumed that cities are automatically excluded from the Sherman Act. City utility projects and programs involving solar facilities must adhere to the constraints of the Sherman Act.

Since the Louisiana case, the question of potential antitrust liability has been raised consistently. It is now essential that municipal advisors consider the potential for antitrust liability prior to the issuance of bonds for a specific enterprise, particularly a utility undertaking.

\subsection{BASIC BOND FORMS: NATURE AND INHERENT LIMITATIONS}

The previous discussion has been directed toward bond issuance in general; both the power to issue bonds and the limitations upon such power. The nature of particular bonds and the inherent limitations of particular bond forms, however, must be understood before the applicability of bond issuance for solar facilities can be cogently considered by municipal officials. Where the power is unlimited and the restrictions few, this type of bond is subject only to the creativity of the bond lawyer and the acceptance of the bond market. Ordinarily, however', the power to issue bonds is limited by state statute and/or by market acceptance.

From the viewpoint of source of bond payment, the most commonly issued municipal bonds are of three distinct types: general obligation bonds, revenue bonds, and special assessment (or improvement) bonds. Two recognized variations of revenue bonds, industrial development bonds and mortgage-backed bonds, are of particular interest to solar 
facility financing. Pollution control bonds (a type of revenue bond) may be of some peripheral interest in solar facility financing but are not discussed here. The primary purpose of such bonds is, as described in Treasury Regulations, Section 1.103-8(g), to abate or control water or atmospheric pollution or contamination by removing, altering, disposing, or storing pollutants, contaminants, wastes, or heat. Bonds with a significant purpose other than pollution control (such as bonds issued to finance solar facilities) ordinarily will not qualify as pollution control bonds, and are outside the scope of this paper.

\subsubsection{General Obligation Bonds}

General obligations bonds are among the most flexible and least costly of public borrowing methods. Though the language of judicial decisions is of ten imprecise [31], it is apparent that two elements are essential to general obligation bonds. First, the bonds must be backed by the full faith and credit of the issuing entity [32], and second, the bonds must be supported by the taxing power of the issuing entity [33]. The fact that bonds are backed by the full faith and credit of the entity and are secured by all the resources of the entity except the taxing power, is not sufficient to term the bonds general obligation bonds [34]. Also, the certainty that the bonds may be payable from taxes does not automatically classify them as general obligation bonds [35]. The combination of the two conditions is the essential prerequisite to general obligation bonds [36].

The support of the taxing power for the bonds is the characteristic of general obligation bonds most carefully examined by the courts. Clearly, the phrase does not mean that the bonds must be paid by taxes; the use of other revenue by the issuing entity to pay the bonds, without resort to the taxing power, is ordinarily proper. [37]. Nor is it essential to the creation of a general obligation that all conceivable tax sources be unrestrictedly pledged to the payment of the obligation. "Certain tax sources or portions thereof may be excluded or excepted, by reason of previous commitment or otherwise, still leaving under pledge the remainder of the comprehensive taxing power" [38].

There is a distinct line of cases establishing what may be called the surplus fund rule. These cases hold that, where the issuing entity has exhausted its taxing power for general expenses, the courts will not compel it either to exceed taxation limits [39], or to divert funds from operating expenses [40] to pay its general obligation debt.

This rule has, however, been severely eroded by judicial decisions. A statute providing that judgments rendered against municipalities be assessed upon taxable property and the amount thereof added to other municipal taxes, required the levy of a tax above a general tax limit to pay a judgment rendered upon defaulted bonds. Therefore, the municipality could not avoid its legal obligation to pay bonds by making its running expenses equal to the limit of taxation. The court noted in Hammond v. Place that, "Poverty ... is no more a defense against just debts in a municipal corporation than in any other corporation or an individual" [41]. Where a tax limitation statute provided that the city. could levy taxes up to a named amount for enumerated purposes, including the payment of debts as well as general operating expenses, the city was required to levy first for debt payment. If remaining revenues were insufficient, the city was to conduct (pursuant to a specific statute therefore) an election to levy an additional tax to meet operating requirements [42]. Taking a somewhat different approach, at least one court found that although the city had exhausted its property tax limit for ordinary expenses, it did not show an exercise of its full power to levy taxes on persons and occupations and to collect fines and penalties. Therefore, it could not avoid its bonded indebtedness [43]. The 
surplus fund rule is most of ten avoided by a determination of the court that a tax limitation statute under consideration relates only to taxes for general municipal purposes. Therefore, the entity may be compelled to levy an additional tax to meet bonded indebtedness [44]. A frequently mentioned rationale for this exception is that "the power to incur a debt includes the power to levy taxes for the discharge of the debt" [45], and "power to levy taxes to pay debts imposes a duty to exercise the power" [46].

Although the surplus fund rule and related tax limitation provisions do not, for the most part, restrict general obligation bond issuance and payment by municipalities [47], debt limitation provisions constitute the fundamental limitation upon general obligation bond issuance. Such provisions may appear in constitutions, statutes, or charters and may take one or more of three forms: a general limit upon the indebtedness of municipalitities [48], a specific limit upon the amount of bonded indebtedness of municipalities [49] or, a specific limit upon the amount of bonded indebtedness which municipalities may incur for particular purposes [50]. In addition, the limitation may relate to the assessed valuation of the entity or to the annual revenues of the entity. Although the limitutions may extend beyond general obligation bonds [51], they are at a minimum directed at such bonds, and it is frequently held that general obligation bonds issued in excess of the limitation are void [52]. It is beyond the scope of this paper to detail the alternative debt limitations and their application in the varying jurisdictions. However, such limitations bear close examination to determine their applicabllity to the particular general obligation bonds proposed to be issued [53]

\subsubsection{Revenue Bonds}

Revenue bonds are obligations of a governmental entity that are payable from the revenues of the enterprise financed by the bonds [54]. Revenue bonds are of ten distinguished from general obligation bonds by statements that they are not a pledge of the full faith and credit of the entity [55], are not an obligation of the entıty [56], or do not represent a debt of the entity [57]. The precise distinguishing feature of revenue bonds is that they are not ultimately supported by the taxing power of the entity; i.e., they will not be retired by any kind of tax of the issuing entity [58]. Stated otherwise, the user's ur belieficiaries of the improvement, rather than the taxpayer, pay for the improvement financed with bonds [59]. This distinction is important because in the broadest sense, revenue bonds do constitute debts and obligations [60]. It has been argued that they may represent the full faith and credit of an issuing entity that does not have the taxing power, if the entity has pledged all its revenue sources to the repayment of the bonds [6 1].

The statement that revenue bonds do not constitute a debt of the issuing entity is ordinarily in the context that the bond in question is not subject to debt limitations applicable to the issuing entity, and it is established that bonds puyable from a special fund are not subject to such limitations [62]. If the tnxing power of the issuing entity can be indirectly reached or is indirectly pledged to the payment of the bonds [6.3], or if the special fund is merely an additional source of repayment of general obligation bonds [64], debt limitations are applicable and the characterization of the bonds as revenue bonds is imprecise, if not improper [65].

An inherent limitation of revenue bonds is that the improvement to be financed must generate revenues, which indicates that the entity must have the authority to cause the generation of such revenues. Thus, if it is proposed that the revenues will be generated from rentals under a lease of the property financed with the revenue bonds, the entity 
must have express or implied authority to lease such property [66]. If it is proposed that the revenues will be generated from tolls, rates, or charges levied for the use of the property financed with the bonds, the entity must have express or implied authority to levy such fees [67]. In some jurisdictions it is held that the power to pledge revenues must be expressly provided to municipal corporations before such a pledge may be made [68], but the majority rule is that the power to issue revenue bonds implies a power to pledge revenues to their repayment.

Although some revenue bond laws authorize a pledge of gross revenues and permit repayment of bonds prior to expenditures for maintenance and operation [69], other laws require a pledge of net revenues so that the upkeep of the facilities is assured prior to bond repayment [70]. In the latter instance, the bonds may default even though the enterprise may continue to function.

In addition to securing bond repayment with a pledge of the revenues derived from the operation of the enterprise financed, many revenue bond laws or related general provisions authorize payment of revenue bonds from entirely distinct, but related, sources of revenue. Thus, the pledge or use of on-street parking meter revenues to pay bonds to finance off-street parking facilities [71], the city's entire parking system revenues to pay bonds issued to finance a single multilevel structure [72], ferryboat operation revenues to pay bonds issued to finance a tunnel project [73], and water system revenues to pay bonds issued to finance sewer systems (and vice versa) [74], has been upheld. The pledge of the proceeds of municipal li cense, exercise, franchise, or utility service taxes to the payment of revenue bonds as additional security has also been upheld [75]. The ability to use or pledge revenues from other (related) sources to the pavment of revenue bonds issued to finance a particular facility does not support the contrary proposition that revenues from the financed facility may be used for other purposes of the issuing entity; i.e., the pledge of revenues to the repayment of revenue bonds "precludes the lawful appropriation of such revenues to any other governmental function of municipal purpose that will be prejudicial to the payment of the debt for which the pledge was given" [76].

\subsubsection{Industrial Development Bonds}

Industrial development bonds are simply a unique form of revenue bond, though statute or city charter may permit the issuance of general obligation bonds for industrial development purposes. Industrial bonds are secured by the revenues of a particular industrial or commercial enterprise and issued for the purpose of overcoming an unfavorable economic situation; e.g., by providing employment, promoting the processing of natural resources, promoting agriculture, or increasing tourism. The revenues are remitted to the issuing entity in the form of lease rental payments, loan repayments, sales contract installments, or other forms. In some states, due to preexisting constitutional limitations (such as those prohibiting the loaning of credit to private corporations) and considerable conflict in the courts concerning the constitutionality of industrial development bonds, such bonds were authorized only after constitutional amendment. In other states, general statutes that authorize such bond issues have been adopted both with and without prior constitutional amendment.

The inherent limitations of such bonds stem primarily from the constitutional and statutory limitations in a particular state. The municipal of ficial embarking upon such a bond issue examines, in particular, the purposes for which the bond may be issued:

- if the statute uuthorizes only industrial development bonds that create employ- 
ment or aid a particular industry;

- if the statute endorses any bond issued for the purpose of aiding the local economy;

- the procedural requirements for issuance (e.g., election requirements);

- if a corporation or an authority inferior to the entity may issue the bonds;

- if the aided enterprise must have an investment grade rating upon its own borrowings;

- if the financing structure is limited to a lease;

- if there may be a sale of the facility to the aided enterprise; and

- if construction must be undertaken by the issuing entity or the aided enterprise.

Municinal advisors should not only examine the content of the industrial development statute, but should scrutinize major court case decisions that uphold the statute in consideration. As is true with many new financing forms, early industrial development bond issues occurred under particular statutory authorizution only after a validating suit thereon had been undertaken and completed in the courts.

\subsubsection{Mortgage-Backed Bonds}

Like industrial development bonds, mortgage-backed bonds are simply a form of revenue bond; their distinguishing feature is the nature of their security. Mortgage-backed bonds are payable from revenues of a facility, but a mortgage upon the facility financed constitutes additional security for bond repayment. The bondholder, through a trustee, can foreclose upon the financed facility as a last resort in obtaining repayment of his debt. The mortgage may be on a facility owned by the issuing entity, if the entity has the authority to mortgage its property. The mortgage also may be upon a facility owned by an enterprise aided by the municipality. This would be particularly common in the case of industrial development bonds or nonprofit corporate undertáking's (e.g., hospituls).

The primary reason for drawing particular reference to mortgage-backed bonds, is because of their use in the area of housing. Mortgage-backed bonds for housing purposes are partially or wholly repaid from home loan payments made by the homeowners and are ordinarily secured by a mortgage on the home. Until recently, housing bonds were pri$\mathrm{m}$ arily issued by states. With the continuance of rising housing costs and the depletion of an adequate supply of housing stock, particularly housing stock available to persons of low and moderate income, municipalities have engaged in the issuarle of bonds for housing purposes. Several such bond issues have been undertaken by municipalities under their home-rule power, but in some states, broad statutes exist which enable bond issuance by municipalities without home-rule powers.

The purpose of housing bonds encompasses acquisition of existing housing, construction of new housing, and reconstruction, improvement, and remodeling of such housing. The latter purpose is ideally suited to improvement of homes for weatherization, energy savings, installation of passive solar systems, and substitution of utility services (e.g., substitution of active solar heating facilities for previously existing gas or electric facilities).

The future of mortgage subsidy bonds is, at this writing, uncertain. H.R. 3712 and simi- 
lar bills have been introduced in the Congress, which would severely curtail the taxxempt status of obligations, the proceeds of which are to be used for mortgages on owner-occupied residences.

\subsubsection{Assessment Bonds}

Like all other forms of financing, assessment financing must satisfy the public purpose test; i.e., it must be in support of an improvement that confers a general benefit upon the public at large within the assessing entity. In addition, it must be in support of a local improvement; i.e., an improvement that confers a special benefit upon the individual properties assessed. The nature of these two tests and their interrelationships is set forth in Federal Construction Company v. H.W. Ensign:

Special benefits to the property to be assessed, that is, benefits received by it in addition to those received by the public at large, is the equitable and just foundation upon which local assessments rest; and under our system of government no assessment can be made upon any land on. any principle other than that of special benefits actually or presumptively received. The elements which an improvement must possess in order to justify a local assessment based on the theory of benefits are certainly two in number, and possibly three. The first is that the improvement must be a public one; that is, it must be one which confers a general benefit upon the public at large, and which, therefore, the public acting through its government, may construct without the consent of the particular individuals affected. An improvement which lacks this element is essentially a private improvement; and no matter how useful or advantageous it $m$ ay be to the owners of private property the public cannot compel its construction, nor can it pay for it by funds raised by the exercise of the sovereign power of taxation. Spring Street Co. v. City of Los Angeles, 170 Cal. 30 (L.R.A. 1918E, 197, 148 Pac. 217); 1 Page and Jones on Taxation by Assessment, sec. 283). The second element essential to a valid local assessment is that the improvement must confer an especial and local benefit upon the property which is to be assessed. It is possible that it will suffice if, from the nature of the work, the property can be presumed to have received an especial benefit. (See 4 Dillon on Municipal corporations, 5th ed., sec. 1440). Unless, however, there be some local benefit, actually or presumptively received, the improvement may be public in character, so that the expense thereof may be borne by general taxation, but a local assessment, levied on the basis of benefits cannot be made therefor; since the underlying the principle of such assessments is that the improvement, aside from the mere gener al advantage resulting to the community at large, will result in some special benefit to the particular lot owners, whose lands are assessed-a special benefit to the assessed lands in which the general public does not participate. (1 Page and Jones on Taxation by Assessment, sec. 284.) It is, however, no objection to the validity of an assessment that the improvement benefits the public, provided it also confers an especial local benefit upon the property to be assessed. Improvements of this sort necessarily must have a dual aspect-an aspect of general benefit to the public as well as one of peculiar local benefit to the lot owners. To invalidate the assesment the general public benefit must be the only result of the improvement. A third element, which is insisted upon in some jurisdictions, is that of permanency. [77] 
Thus, if the benefit conferred upon the properties proposed to be assessed for the improvement is not distinguishable from the benefit conferred upon properties in the community as a whole, assessment financing will not be upheld [78] .

In determining whether the property that is proposed to be assessed receives a special benefit from the proposed improvement, it has been stated that benefit is not measured solely by the enhanced value of that property, but that other factors (e.g., health and sanitation) are relevant [79]. The majority of cases appear to concur with the statement that, "(s)pecial benefits to assessed lands must be pecuniary benefits which increase their

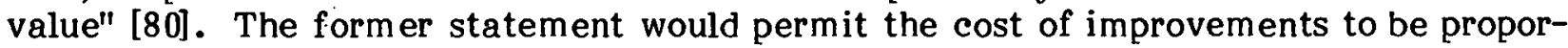
tionately spread over the properties benefited and would necessarily involve great subjectivity, and the latter statement would place a ceiling on the amount assessed on any particular property in the form of enhanced fair market value [81]. This ceiling is found in several state constitutions and stutules [82]. The revognition of such a ceiling appcare mandated by holdings that, when the chance of the cost exceeding benefits increases (in terms of the amount of the individual assessment) and the amount of the not improbablc excess is great, the assessment will be overturned [83].

Closely related to this rule of benefit is the generally accepted rule that although benefits need not be direct or immediate, they must have a better basis than mere speculation or conjecture [84]. Attempts to find or measure benefit, as expressed by increased fair market value of the property assessed, will cause the assessing entity to be open to allegations that the assessments are based merely upon speculation or conjecture.

In addition to determining that the assessment of any particular property is proportionate to the benefit conferred upon that property, it also must be found that the assessment levied upon any particular property is proportionate to other property assessments [85]. To assure the proportionality between properties, a number of formulae have becn upheld [86]. Unless the formula is prescribed by statute [87], any method of determining proportional benefits would appear to be proper if it results in a just and equitable spread of the cost over the benefited properties [88].

Finally, in determining the validity in terms of amount of any assessment, it should be noted that specific maximums are frequently found in law authorizing the statute. Thus, it is stated:

express limitations are common in statutes, ordinances and municipal charters, as that the burden shall not exceed twenty, twenty-five, forty, fifty or seventy-five percent of the value of the land or property assessed, or one-half, or one-third of the value thereof. [89]

The preceding comments are directed primarily toward financing the initial cost of an improvement through assessment proceedings: However, some judicial decisions and statutes refer to assessments for the "use" of an improvement in addition to assessments for construction [9.0]. Assessments for use, it is stated, differ from "use charges," in that they are based upon benefit to land and do not constitute a personal charge for the use of sewers [91]. Applications of revenues from assessments for use, to repayment of bonds for construction of lateral sewers [92], sewer maintenance [93], (where there was not a constitutional limitation upon capital improvements), and bonds given to finance the construction of a sewage disposal plant [94], have been upheld.

Assessment financing may take one of several forms; e.g., the improvement financed may be paid directly by lump-sum cash payments of assessments [95], by installments of 
assessments [96] to repay bonds or certificates issued to the public works contractor [97], at a public sale [98], or any combination of the foregoing [99]. Regardless of which method is selected, assessments upon property constitute the primary security for the undertaking. By statute, these assessments constitute a lien upon the property assessed [100], and are enforceable by proceedings against the land assessed [101] rather than the owner thereof [102]. As a result, the land assessed may be sold to pay the lien, but the owner thereof is not personally liable [103] unless the statute provides otherwise [104]

In addition to the security offered by the assessment and consequent lien, a number of assessment laws provide secondary repayment sources for assessment financing. For example, the following secondary sources have been upheld by the courts: a special revolving fund comprised of revenues of general taxes levied to meet the needs of the fund with payment therefrom considered loans [105], an ad valorem tax upon all properties in the issuing entity in an amount sufficient to pay the defaulted assessment [106], a guaranty fund replenishable from the issuing entity's general fund or other available sources [107], a requirement for payment of delinquent assessments from any unappropriated funds of the city [108], an obligation to purchase land sold for delinquent assessments from the general fund [109], and an authorization to issue bonds to refund delinquent improvements bonds [110] . Generally, these secondary sources have been upheld against allegations of violation of debt limitations [111], "double" taxation [112], gift of public funds [113], taking of property without just compensation [114], and similar allegations of unconstitutionality [1 15$]$.

Assessment bonds may be particularly appropriate for the financings of active solar heating and cooling systems for residential purposes.

\subsection{FEDERAL TAX CONSIDERATIONS}

The previous discussion concerned the power to issue bonds in general, the limitation upon such power, and the unique characteristics of several basic bond forms. In Section 3.0, the bond laws of particular states and their applicability to the forms of solar energy mentioned previously, will be discussed. Initially, the applicability of federal tax restrictions to the issuance of bonds for solar facilities of the type outlined must be examined, for it is clear that the primary motivation behind municipal financing of solar facilities is to enable such financing at low-interest costs. The interest on properly qualifying municipal bonds is tax exempt in the hands of the bondholder. For that primary reason, municipal bonds command a lower interest rate on the bond market, and the application of relevant federal tax regulations to bonds issued for the solar facilities under consideration must be examined.

The scope of this section is limited to a discussion of the problem areas involved in determining whether the interest on governmental obligations issued to provide solar energy facilities is exempt from federal income tax. The types of solar systems that this analysis addresses are residential solar heating and cooling, agricultural and industrial process heat, biomass conversion, wind-power installations, ocean thermal energy conversion, solar thermal conversion, photovoltaics, and solar-powered satellites. For purposes of simplicity, this discussion assumes that there is state authority for issuing solar energy bonds, that such bonds will be issued by a state or a political subdivision of a state (thereby avoiding the issue of whether such obligations are-issued by or on behalf of a governmental unit), and that the arbitrage requirements of Section 103(c) of the Internal Revenue Code of 1954, as amended (the Code), are satisfied. Thus, the problems presented by the industrial development bond provisions of Section 103(b) of the Code, are emphasized. 
Section 103(a) of the Code provides that interest on an obligation of a state or political subdivision of a state, is exempt from federal income taxation. Section 103(b) of the Code provides that interest on an industrial development bond is not exempt from federal income taxation because it is not treated as, an obligation or political subdivision of a state. However, the interest on such an obligation would be tax exempt if it qualified under one of the special activities exemptions provided by Section 103(b)(4) or (5) of the Code, or under the small issue exemption provided by Section 103(b)(6) of the Code.

Thus, a discussion of the problems presented by the industrial development bond provisions on the tax-exempt status of solar energy bonds involves two inquiries: (1) the governmental obligation must be examined to ascertain whether it is an industrial development bond, and (2) if it is such a bond, then it must be determined whether it qualifies under one of the special activities exemptions or under the small issue exemption.

\subsubsection{Solar Energy Bonds as Industrial Development Bonds}

Section 103(b)(2) of the Code defines an industrial development bond as any obligation that is issued as part of an issue in which all or a major portion of the proceeds are used directly or indirectly in any trade or business carried on by any person who is not an exempt person; and, the payment of the principal and interest which is in whole or in major part either (1) secured by any interest in property used or to be used in a trade or business, or by payments in respect to such property, or (2) to be derived from payments in respect to property or borrowed money used or to be used in a trade or business. An exempt person is defined by Section 103(b)(3) of the Code as either a governmental unit or an organization described in Section $501(\mathrm{c})(3)$ of the Code, but only with respect to a trade or business which is not an unrelated trade or business.

Thus, two tests are embodied in the statutory definition of an industrial development bond. First, the payment of the principal and interest on the bonds must be secured by or derived from some interest in property that is used in a trade or business (the security interest test), and second, the bond proceeds must be used in the trade or business of a nonexempt person (the trade or business test).

\subsubsection{The Security Interest Test}

The security interest test relates to the nature of the security for, and the source of, the payment of either the principal or interest on a bond issue. Thus, Treasury Regulations, Section 1.103-7(b)(1)(ii) specifies that the security interest test is satisfied if the payment of the principal or interest on a bond issue is in whole or major part (1) secured by an interest in property used or to be used in a trade or business, (2) secured by any interest in payments made in respect to property used in a trade or busines, or (3) to be derived from payments in respect to property, or borrowed money, used in a trade or business. As a result, if solar energy facilities are provided to certain users, the payment of the interest or principal on the solar energy bonds is to be secured by an interest in those facilities, and the solar energy facilities are to be used in a grade or business, the security interest test will be satisfied. Furthermore, if the solar energy facilities are to be leased, or loans are to be made for the purpose of financing the purchases of such facilities, and the payment of the principal or interest on the solar energy bonds is to be derived from the lease or loan payments, the security interest test will be satisfied if the solar energy facilities are to be used in a trade or business [116]. 
Moreover, Treasury Regulations, Section 1.103-7(b)(4) provides that the nature of the security for, and the source of, the payment of either the principal or interest on a particular issue of bonds does not have to be determined on the basis of the bond indenture alone but may be determined on the basis of an underlying arrangement. Those regulations indicate that an underlying arrangement may result from separate agreements between the parties or may be determined on the basis of all the facts and circumstances surrounding the issuance of the bonds. Those same Regulations also provide that a pledge of the full faith and credit of a state or local governmental unit will not prevent a debt obligation from otherwise satisfying the security interest test. Thus, if the payment of either the principal or interest is secured by both a pledge of the full faith and credit of a state or local governmental unit and any interest in property used or to be used in a trade or business, the security interest test is satisfied.

Treasury Regulations, Section 1.103-7(c), Example 14, illustrates the expansive application given the security interest test rules. Following that example, J (a political subdivision of a state) will issue bonds, the proceeds of which will be used to rehabilitate urban buildings that will be sold or leased to nonexempt persons for use in their trades or businesses. Although there is no formal arrangement whereby revenues from a particular project are to be paid into a trust or sinking fund, there is the unconditional obligation of $J$ to pay the principal and interest on the bonds. The example concluded that it was apparent that $J$ requires the revenues from the lease or sale of buildings to nonexempt persons in order to pay in full the principal and interest on the bonds in question. Thus, the security interest test is met because, pursuant to an underlying arrangement, the major payment of the principal and interest on the bonds is to be derived from payments in respect of property or borrowed money used in the trades or businesses of nonexempt persons [1-17].

Even if solar energy bonds were issued as general obligation bonds and no assets or payments were pledged as security for the bonds, the security interest test would still be satisfied if it were apparent that revenue obtained from the sale or lease of solar energy facilities would be needed to pay in full the principal and interest on the bonds in question. However, if bond service was totally satisfied from general tax revenues and the revenue obtained from the solar energy facilities would in no way be needed or used for bond service, the security interest test would not be satisfied, and the bonds would not be industrial development bonds.

The security interest test is so broad that it is almost impossible for most obligations not to fall within its scope [118]. Consequently, the property which is the security for or the source of the payment of either the principal or interest on the issue of bonds must be property that is used in a trade or business. Whether a particular issue of bonds is an issue of industrial development bonds is determined by the trade or business test.

\subsubsection{The Trade or Business Test}

To meet the trade or business test, a major portion of the proceeds of the solar energy bond issue must be used in the trade or business of a nonexempt person. The term "major portion" has been specifically defined by Treasury Regulations, Section 1.103-7(b)(3)(iii) as the direct or indirect use of more than $25 \%$ of the proceeds of an issue by nonexempt persons in their trades or businesses. Thus, if less than a major portion of the proceeds of a solar energy bond issue is to be used in the trade or business of a nonexempt person, the trade or business test has not been satisfied. Moreover, Treasury Regulations, Section $1.103-7(b)(3)($ ii) provides that the indirect as well as the direct use of the 
proceeds is to be taken into account in determining whether an obligation meets the trade or business test. Therefore, as those Rcgulations point out, an obligation satisfies the trade or busines test if the governmental unit uses the proceeds to finance the construction or acquisition of property to be used by a nonexempt person in his trade or business, or if the governmental unit uses the proceeds to construct a facility which is to be leased or sold to a nonexempt person for use in his trade or business. Under that indirect use rationale, it is clear that the use of solar energy bond proceeds by a governmental unit to acquire solar energy facilities (which are to be sold or leased to nonexempt persons), would satisfy the trade or business test if the facilities were to be used by those nonexempt persons in their trades or businesses. Accordingly, the use of bond proceeds to provide a fund from which low-cost loans would be made to nonexempt persons for the purpose of acquiring solar energy facilities, would satisfy the trade or business test if the solar energy facilities were to be used by those nonexempt persons in their trades or businesses.

As is readily apparent, the determination of whether the trade or business test is satisfied depends upon the type of solar energy facility involved and upon the context in which the facility is used. Thus, this analysis will proceed by applying the trade or business test to the various contexts in which the eight distinct types of solar energy facilities, indentified previously, might be used.

Residential Solar Heating and Cooling Systems-Active and Passive. Residential solar heating and cooling systems, which are the most readily recognized of the solar facilities, include both active and passive systems. These systems can be used in a number of comm on situations, including their installation on single-family residences, on condominiums and cooperatives, or possibly on multiple-unit rental complexes. This segment analyzes the applicability of the trade or business test to those situations.

Although there are a number of methods that might be utilized to provide solar energy facilities to single-family residences (or to condominiums and cooperatives, rental complexes, etc.), the most feasible methods seem to be: (1) the governniental unit would install and sell the solar energy facility to the homeowner, (2) the governmental unit would install and lease the solar energy facility to the homeowner, (3) the governmental unit would install the solar energy facility and let the homeowner use it for a use charge, or (4) the governmental unit would use the proceeds of the solar bond issue to establish a fund from which it would make low-cost loans to homeowners for the purpose of financing the acquisition and installation of solar energy facilities [119].

Single-Family Residences. The installation of a solar energy facility on a residence raises the question of whether the homeowner is using that residence in a trade or business. Even though the residence is being used by a nonexempt person, that residence is not bcing used in a lade or business if it is being used solely for living purposes [120]

In such a case, the trade or business test would not be met and the bonds would not be industrial development bonds. However, if the governmental unit did not deal directly with the homeowner but used the local water, gas, or electric utility as a middlcman, thcre would be a substantial question raised regarding that middleman's use of the solar energy bond proceeds in its trade or business.

An additional problem is raised when a solar energy facility is provided (through sale, lease, or financing) to a residence that is owned by an investor who leases or rents that 
residence to a tenant. Since the investor-owner of the residence is in the business of leasing or renting property, it is clear that such bond proceeds are being used in a trade or business. Because a substantial proportion of residences in an urban area are investorowned, the use of proceeds to provide solar energy facilities to such residences would present a critical problem. If a major portion (more than 25\%) of the bond proceeds were used in such a manner, the trade or business test would be satisfied and the solar energy bonds would be industrial development bonds (assuming the security interest test were also satisfied). A possible solution to this problem is to restrict the program to owneroccupied residences.

Another problem is presented by a small number of homeowners who use one or more of the rooms in their residences as an office from which they operate a business (e.g., salesmen, accountants, writers, artists, tax-return preparers). Though it is evident that the residence is being used in a particular trade or business, in this situation a major portion (more than $25 \%$ ) of the bond proceeds would have to be used to provide solar energy facilities to such residences before the trade or business test would be satisfied.

Condominiums and Cooperatives. A slight variation of the situation presented by singlefamily residences is the provision (through sale, lease, financing, etc.) of solar energy facilities for condominiums and cooperatives. Undoubtedly, one solar energy facility would be installed on the building and would be used by all owner-occupants of that building. The only difference between a condominium-cooperative situation and a singlefamily residence situation would be that the solar energy facility installed on a condominium or cooperative would be used by all the owner-occupants of the building. If the solar energy facility were owned by or leased to the owner-occupants of the condominium or cooperative for use in their residential units, no industrial development bond problem is foreseen because the solar energy facility would not be used in a trade or business. However, if the solar energy facility were to be provided to the management entity which manages and maintains the building, for example, then a possible trade or business problem would be raised. It could be argued with a degree of merit that the bond proceeds were being used by the management entity in its trade or business of managing and maintaining such a building. As with single-family residences, it should be noted that the problems of the home-office and the investor-owner are also present in a condominium-cooperative situation. An additional problem presented by the condominium-cooperative situation is the presence of small retail establishments in a condominium or cooperative (usually on the first floor). If those retail establishments are to be benefited by the solar energy facility installed in the building, it is evident that the proceeds of the solar bond issue will be used in their trades or businesses. However, if. the retail establishments comprise less than $25 \%$ of the total floor area which is benefited by the solar energy facility, the trade or business test would not be satisfied [121] .

Multi-Unit Rental Complexes. If a solar energy facility is installed on an apartment complex, there is no doubt that the trade or business test is satisfied because the solar energy facility will be used by the owner of the apartment complex in his trade or busiliess of renting apartment units Thus, an issue of solar energy bonds used in such a manner would be industrial development bonds, assuming the security interest test were also satisfied.

In summary, if the proceeds of a solar energy bond issue are used to provide solar energy facilities for single-family residences, condominiums, or cooperatives, those bonds would normally not be characterized as irdustrial development bonds (assuming that the prob- 
lem areas considered in the discussion of those situations are avoided; e.g., the homeoffice and investor-owned problems). However, if the proceeds of a solar energy bond issue are used to provide solar energy facilities for multi-unit rental complexes, the trade or business test would be satisfied; the bonds would be characterized as industrial development bonds, assuming the security interest test were also satisfied. Therefore, it is necessary to determine whether bonds used for such a purpose would qualify under one of the special activities exemptions of Section 103(b)(4) or (5) of the Code or under the small issue exemption of Section 103(b)(6) of the Code.

Agricultural and Industrial Heat Systems. By definition, an agricultural or industrial heat system would meet the trade or business test because such a facility would be used in the trade or business of a nonexempt person. Thus, if the proceeds of solar energy bonds were used to provide agricultural or industrial heat systems, those bonds would be characterized as industrial development bonds, assuming the security interest test were also satisfied.

Biomass Conversion Systems. Whether solar energy bonds are industrial developmint bonds is determined by the character of the use of such a facility. The proceeds of solar energy bonds would be used to provide biomass conversion systems that convert waste materials (e.g., cattle manure and garbage) into natural gases that can be used to operate electric generators. Again, if the facility is used by a nonexempt person in his trade or business, the trade or business test will be met, and the bonds will be industrial developinent bonds. An illustrative example would be the use of the proceeds of solar energy bonds to finance the construction of a biomass conversion system for an investor-owned utility. However, if the biomass conversion facility were operated by an exempt person, such as a municipality, which would use the natural gas produced from the facility to fire its electric generating plant, the trade or business test would not be met and the bonds would not be industrial development bonds.

Wind-Power Installations and Photovoltaic Systems. If solur bond proceeds were used to finance the installation of wind-power or photovoltaic systems on single-family, owneroccupied residences, the trade or business test would not be met. However, if windpower or photovoltaic systems were installed on rental units or put to an industial or agricultural use, the trade or business test would be met. If a "farm" of wind-power systems were installed and the power generated were used to provide electricity to a nearby community, the bonds issued to finance such a facility would be industrial development bonds if the "farm" were operated by a nonexempt person, such as an investorowned utility. However, if the "farm" were operated by an exempt person, such as a municipal utility, the bonds would not be characterized as industrial development bonds because the trade or business test would not be met. A similar result would be obtained if a series of photovoltalc systems were used in a like manner.

Ocean Thermal Energy Conversion, Solar Thermal Conversion, and Solar Power Satellite Systems. Given the magnitude and expense of constructing and operating an ocean thermal energy conversion system, a solar thermal conversion system, or a solar power satellite system, such a system would be required to be operated by either a governmental unit or a large and financially capable privately owned utility company. If the ocean thermal conversion system, the solar thermal conversion system, or the solar power satellite system were operated by a governmental unit, the trade or business test would 
not be met and the solar energy bonds used to finance such a facility would not be industrial development bonds. However, if one of the facilities were operated by a privately owned utility, the trade or business test would be met.

\subsubsection{Qualification of Solar Energy Bonds Under Special Activities or Small Issue Exemptions}

For those issues of solar energy bonds which meet the definition of an industrial development bond, a separate examination must be made to determine if those bonds qualify under any of the special activities exemptions provided by Sections 103(b)(4) or (5) of the Code or under the small issue exemption provided by Section 103(b)(6) of the Code [122].

\subsubsection{The Special Activities Exemptions}

Section 103(b)(4) provides an exemption for obligations that are issued as part of an issue, in which substantially all of the proceeds are to be used to provide:

- residential real property for family units,

- sports facilities,

- convention or trade show facilities,

- airports, docks, wharves, mass commuting facilities, parking facilities, or storage or training facilities directly related to any of the foregoing,

- sewage or solid waste disposal facilities for the local furnishing of electric energy or gas,

- air or water pollution control facilities, or

- facilities for the furnishing of water, if available on reasonable demand to members of the general public.

In addition, Section 103(b)(5) provides an exemption for bonds used to provide certain industrial parks.

There are three special activities exemptions which potentially apply to solar energy facilities: (1) residential real property for family units; (2) facilities for the local furnishing of electric energy or gas; and (3) facilities for the furnishing of water. Each will be analyzed in detail.

Residential Real Property for Pamily Units. To qualify under the residential real property for family units special activities exemption, the facility which must be provided is a "family urit." Family units are defined by Treasury Regulations, Section 1.103-8(b)(2)(i) as "a building or any portion thereof which contains complete living facilities which are to be used on other than a transient basis by one or more persons and facilities functionally related and subordinate thereto." For example, a house or an apartment which is to be used on other than a transient basis by either a single person or by a family, which contains complete facilities for living, sleeping, eating, cooking, and sanitation, constitutes a family unit. 
Passive Solar Heating and Cooling Systems. As previously indicated, passive solar heating and cooling systems are an integral part of the design of the building or residence in which they are incorporated. Thus, using the residential real property for family units special facilities exemption, tax-exempt solar energy bonds could be issued with the proceeds being used to finance the construction of rental houses or an apartment complex which would incorporate a passive solar heating and cooling system in its design.

Active Solar Heating and Cooling Systems. Treasury Regulations, Section 1.103-8(a)(3) provides that an exempt facility (i.e., residential real property for family units or sports facilities) includes any land, building, or other property "functionally related and subordinate to such a facility," if the functionally related and subordinate property is of a character and size commensurate with the character and size of the exempt facility. Treasury Regulations, Section 1.103-8(b)(ii) indicates that facilities which are functionally related and subordinate to residential real property actually used for family units include; e.g., facilities for use by the occupants such as a swimming pool, a parking area, or recreational facilities.

Given the "functionally related and subordinate" concept, the question arises whether an active residential solar heating and cooling system which is clearly not a family unit, is functionally related and subordinate to a family unit, and if so, whether bond proceeds may be used to provide such a related facility without also providing the family unit. Although it could be argued that bond proceeds could be used to provide only a related facility (such as an active residential solar heating and cooling system), without also providing the exempt facility, the safer approach is to recognize that the Regulations contemplate the use of bond proceeds to provide a related facility only in conjunction with the provision of the exempt facility; i.e., the family unit.

A contrary approach would have the effect of raising the "functionally related and subordinate" section of the Treasury Regulations; i.e., Section 1.103-8(a)(3), to the level of an independent special activities exemption. Clearly, such a result would not be in accord with Congressional intent. Congress, while enacting Section 103(b)(4) of the Code, provided an exemption for seven specifically enumerated exempt activities (residential real property, sports facilities, etc.) and made no provision for any functionally related and subordinate exemption.

It should be noted that H.R. 3712 and related legislation recently introduced in Congress amends the exemption for residential real properties for family units, to limit the exemption to multi-family residential property where at least $20 \%$ of the units are occupied by individuals of low or moderate income.

Facilities for the Local Furnishing of Electric Energy or Gas. To qualify under this special activities exemption, the facility which must be provided is a "facility for the local furnishing of electric energy or gas." That terminology is defined by Treasury Regulations, Section $1.103-8(f)(2)($ iii) as property which:

- is either depreciable property or land,

- is used to produce, collect, generate, transmit, store, distribute, or convey electric energy or gas,

- is used in a trade or business of furnishing electric energy or gas, and 
- is a part of a system providing service to the general populace of one or more communities or municipalities, but in no event more than 2 contiguous counties or one county and one city [123].

Furthermore, those Regulations provide that the term "facilities for the local furnishing of electric energy or gas" does not include coal, oil, gas, nuclear cores, or other materials performing a similar function. The language of that Regulation not only excludes the fuel used to fire an electric generating facility (e.g., coal, oil, gas, nuclear cores) but also emphasizes that facilities other than those used to provide electric energy or gas are not included within the exemption.

Of interest in connection with solar facilities, however, is that the regulation clearly favors facilities serving limited geographical areas.

Residential Solar Heating and Cooling and Agricultural Process Heat Systems. Such systems do not generate or supply electricity, but merely heat water that is used either in the hot water or heating systems of a residence or other building. Thus, since residential solar heating and cooling and agricultural and industrial process heat systems are not a part of a system which generates or distributes electric energy or gas, this exemption does not apply.

Biomass Conversion Systems. The type of biom ass conversion system which is the subject of this analysis (because the concern here is solely with the exemption for facilities furnishing gas and electricity) produces various combustible gases, which are in turn used to fuel an electric generating facility. Thus, the biomass conversion system would fall within the "facilities for the local furnishing of gas" exemption, and its accompanying electric generating plant would fall within the "f acilities for the local furnishing of electric energy" exemption. However, it should be noted that the electrical distribution system to which the electric generating plant supplies electricity can be an area no greater than two contiguous counties or one county and one city.

Wind-Power, Photovoltaic, Solar Thermal, Ocean Thermal, and Satellite Systems. Each of these systems produces electricity. Thus, if the "two-county rule" is satisfied, such systems would qualify under the facilities for the local furnishing of electric energy exemption.

Facilities for the Purnishing of Water. Treasury Regul ations, Section 1.103-8(h) provides an exemption for certain water facilities. This exemption applies if substantially all the proceeds of a bond issue will be used to provide facilities for the furnishing of water, and if they are available, on reasonable demand, to members of the general public. Although active residential solar heating and cooling systems and agricultural and industrial process heat systems will heat water that has been obtained from an existing water system, their function is not to furnish water to members of the general public. Therefore, this exemption would not apply [124].

\subsubsection{The Small Issue Exemption}

As can be seen, the special facilities exemptions provided by Section 102(b)(4) of the 
Code, discussed previously (i.e., residential real property for family units, facilities for the local fumishing of electric energy or gas, or facilities for the furnishing of water) do not apply to agricultural and industrial heat systems, active residential solar heating and cooling systems installed on rental residences, or on apartment complexes. However, the small issue exemption provided by Section $103(b)(6)$ of the Code does cover those situations.

In addition to providing exemptions for bonds which will be used to provide certain enumerated facilities, Congress provided an exemption in Section 103(b)(6) of the Code for certain small issues of industrial development bonds. An exempt small issue is an issue of $\$ 1$ million or less, where "substantially all" [125] of the proceeds will be used for the acquisition, construction, reconstruction, or improvement of land or property of a character subject to the allowance for depreciation under Section 167 of the Corie [1 26]. It should bc noted, howevel', thlut Treasury Kegulations, Section 1.103-10(6)(1) provides that under the small issue exemption, no more than an insubstantial amount of hnnd proceeds (10\% or less) can be used to provide working capital or to finance the purchase of invell= tury.

The $\$ 1$ million limitation on a particular new issue is computed by aggregating the face amount of the new issue with the face amount of any prior outstanding exempt small issue [127]. This aggregation is made only to the extent that proceeds of any prior issues were used to finance facilities located in the same county or municipality in which the facility to be financed with the new issue is located [128]. In contrast with the exemptions provided by Section 103(b)(4) and (5) of the Code, the small issue exemption can be used to finance any type of industrial facility. Thus, this exemption would specifically apply to agricultural and industrial process heat systems and active residential solar heating and cooling systems installed on rental residences or apartment complexes.

Pursuant to Section 103(b)(6)(D) of the Code, an issuer may also elect to increase the $\$ 1$ million limitation to $\$ 10$ million [129]. If such a decision is made, in addition to the aggregation rule for issues of $\$ 1$ million, capital expenditures must be counted loward the $\$ 10$ million limit [130]. These expenditures (with certain exceptions) are macle by the principal user of the facility to be financed or by any persons related to that principal user, within the same count $y$ or incorporated municipality during the three years preceding and three years following the issuance of the new bonds.

It is imperative that the capital expenditure rule be followed. If the $\$ 10$ million limitation is exceeded during the three years following the issuanre of the bonds, the cntire issue loses its tax exemption.

If solar energy bonds are to qualify under the small issue exemption, the substantial user concept is of importance. Section 103(b)(7) of the Code provides that interest paid on obligations issued under the small issue exemption provided in Seotion 103(b)(6) of the Code, which are held by a substantial user of that facility (or a person related to a substantial user), is includable in the income of that substantial user (or related person) during the period the obligation is so held [131]. Treasury Regulations, Section 1.10311 (b), defines a substantial user generally as "any nonexempt person who regularly uses a part of such facility in his trade or business." The Regulations further indicate that a nonexempt person is a substantial user if the facility is specifically contructed, reconstructed, or acquired for that nonexempt person. Moreover, a nonexempt person will be deemed to be a substantial user of a facility if he derives $5 \%$ or more of the total revenue derived by all users of the facility, or occupies $5 \%$ of more of the usable area of the facility. Thus, for example, if the owner of a business situated in a shopping center 
which occupies more than $5 \%$ of the usable area of the shopping center, and which is supplied with heat and hot water generated from a central solar energy facility serving the entire shopping center financed with the proceeds of solar energy bonds, is considered a substantial user of the solar energy facility. If that individual buys those solar energy bonds, the interest on the bonds will be taxable because he fulfills the substantial user requirements.

\subsubsection{Conclusion}

The results of this analysis can best be presented in tabular form. It will be noted from an examination of Table 2-1 that in the situations examined, if the solar energy bonds should be characterized as industrial development bonds, those bonds may be qualified under one of the special facilities exemptions or under the small issue exemption. 


\section{Table 2-1. SUMMARY OF TAX CONSIDERATIONS RELATING TO SOLAR ENERGY}

\begin{tabular}{|c|c|c|c|}
\hline & $\begin{array}{l}\text { Furnishes } \\
\text { Electric } \\
\text { Energy }\end{array}$ & IDB & $\begin{array}{l}\text { Available } \\
\text { Exemption }\end{array}$ \\
\hline \multicolumn{4}{|l|}{$\begin{array}{l}\text { Residential Solar Heating \& Colling } \\
\text { Active Systems }\end{array}$} \\
\hline 1. owner-occupied & No & No & - \\
\hline 2. rental unit & No & Yes & "small issue" \\
\hline Passive Systems & & & \\
\hline 3. owner-occupied & No & No & - \\
\hline 4. rental unit & No & Yes & "restential issue" \\
\hline \multicolumn{4}{|l|}{ Agricultural \& Industrial } \\
\hline Process Heat & No & Yes & "small issue" \\
\hline \multicolumn{4}{|l|}{ Biomass Conversion } \\
\hline 1. operated by govt. unit & Yes $^{\mathrm{a}}$ & No & - \\
\hline 2. operated by private utility & Yes $^{\mathbf{a}}$ & Yes & $\begin{array}{l}\text { "electric energy" } \\
\text { or gas }\end{array}$ \\
\hline \multicolumn{4}{|l|}{ Wind Power and Photovoltaics } \\
\hline 1. owner-occupied residence & Yes & No & - \\
\hline rental unit & Yes & Yes & "electric energy" \\
\hline 3. industrial or agricultural use & Yes & Yes & "electric energy" \\
\hline operated by govt. unit & Yes & No & - \\
\hline 5. operated by private utility & Yes & Yes & "electric energy" \\
\hline \multicolumn{4}{|l|}{$\begin{array}{l}\text { Solar Thermal, Ocean Thermal, } \\
\text { and Sülur Sutelltí }\end{array}$} \\
\hline 1. operated by govt. unit & Yes & No & - \\
\hline 2. operated by private utility & Yes & Yes & "electric energy" \\
\hline
\end{tabular}

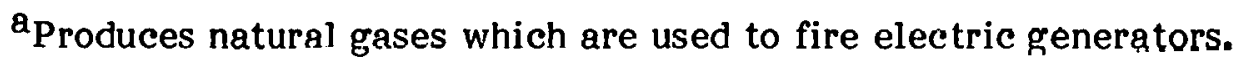




\section{SECTION 3.0}

\section{SPECIFIC BOND LAWS}

\subsection{INTRODUCTION}

This section of the report will examine specific bond laws in five representative states (California, Florida, Illinois, New Mexico, and New York) to determine whether such laws, without amendments, would permit the financing of the eight types of solar facilities outlined in Section 1.0.

\subsection{CALITORNIA}

\subsubsection{General Obligation Bonds}

Under California statutes, a city may issue general obligations bonds "for any municipal improvement" [132]. "Municipal improvement" is defined to include "light and power works or plants" and "other works, property, or structures necessary or convenient to carry out the objects, purposes and powers of the city" [133]. This statutory language is broad enough to authorize general obligation bond financing of each of the eight types of solar energy facilities under consideration.

\subsubsection{Revenue Bonds}

California statutes authorize the issuance of revenue bonds for "the acquisition, construction, or improvement of any enterprise" [134], which is "revenue-producing," and "used for or useful for" [135] one of several stated purposes.

Revenue bond financing of most biomass waste conversion systems is clearly authorized by statute, for one category of approved "enterprise" is a system used for the "collection, treatment or disposal of garbage or refuse matter" [136]. Enterprise further includes "(g)arbage trucks, equipment, dumps, garbage disposal plants and incinerators or other disposal facilities, including facilities to sort and prepare components of solid waste for calc" [137]. Thus, the entire waste conversion system from collection to point of sale is comprehended by the revenue bond statute.

Nevertheless, cities contemplating revenue bond financing of biomass waste gasification plants may be thwarted by the statutory provision which excludes from the definition of enterprise any "systems, plants, works, or undertakings for .... (t)he generation, production, transmission, and distribution of gas for public or private uses" [138].

Wind-power installations, ocean thermal energy conversion systems, solar thermal conversion systems, photovoltaics, and solar-powered satellites are facilities used to generate electricity. Revenue bond financing of such facilities is authorized by the Calif ornia statute which includes in its definition of enterprise the "generation, production, or transmission of electric energy for lighting, heating, and power for public or private uses" [139]. The "distribution of electric energy for lighting, heating, and power for public or private uses" is, however, excluded from the definition of enterprise [140] . Revenue bond financing for the listed facilities, therefore, would be required to exclude 
any portion of such facilities used for distribution of the electricity.

Solar energy can provide heated water to domestic, agricultural, and industrial users. Revenue bond financing of heated water production appears to be authorized because enterprise includes the "obtaining, conserving, treating and supplying of water for domestic use, irrigation, .... industrial use, ... or any other public or private uses" [141]. As in the case of biomass conversion, revenue bond financing of hot water production is authorized up to the point of sale, for enterprise includes "water supply, storage and distribution facilities and equipment" [142].

The California statues do not appear to approve revenue bond financing of solar energy devices designed to heat and cool air. Arguably some solar collectors use water as a heat storage medium, and therefore "treat" water within meaning of the statute [143], thus rendering themselves capable of being financed. But such argument is not available for air systems that use rock beds for storage. The safest course here is to seek statutory amendment.

\subsubsection{Industrial Development Bonds}

The California statutes do not include an industrial development bond law.

\subsubsection{Assessment Bonds}

According to the Improvement Act of 1911 [144], California cities may issue bonds [145] to finance specified improvements "of any ... streets, places, public ways, or property, easements, or rights-of-way" [146].

One type of work authorized for financing is a municipality's water supply; i.e., "(w)ells, pumps ... pipes .... or other appurtenances for supplying or distributing a domestic or industrial water supply" [1471. Under this provision cities can fund construction of centrally located solar-powered plants and related facilities to generate and distribute hot water. Though buildings are expressly excluded in the statute's list of approved works for financing, a California case holds that the statute nevertheless authorized city trustees to construct necessary buildings required for a water works [148].

By the same reasoning, a municipality can erect a biomass gasification plant and distribute its product to domestic and industrial users, for the statute authorizes financing of "(m)ains . . . or other appurtenances for supplying or distributing a domestic or industrial gas supply" [149].

Photovoltaic solar cells can be installed to provide electric power to street lights and related facilities under the statutory uulhorizution for improvements in lighting: "Polet, post, wires, . . . lamps and other suitable or necessary appliances for the purpose of lighting said streets, places or public ways ... or for the purpose of furnishing electricity and electric service or telephone service to property within a city" [150].

Yet another California statute, the Municipal Improvement Act of 1913 [151], authorizes financing of five categories of improvements which municipalities "may install in or along its streets" [152] and, in addition, provides that the municipality: 
may acquire any works ... already installed in the streets ... which are necessary or convenient to supply the municipality or its inhabitants with water, electricity, gas, or other means of heat, illumination, power, or any other public service, and any plants ... which are necessary or convenient for their use and operation. [153]

Under these statutory provisions, a municipality may finance either the construction or later acquisition of any solar-powered electrical generating facility which provides electricity on a local scale. One approved category of improvement is "(l) ines, conduits, and other necessary works and appliances for providing electric power service" [154]. Plants producing electricity generated by oceans and solar-powered satellites are probably not appropriate subjects for such financing, but the acquisition of systems powered by wind, solar thermal energy, and photovoltaics can be financed if the benefit of the systems is local in nature.

Similarly, municipalities can acquire or construct biomass gasification distribution facilities because "(m)ains, pipes, and other necessary works and appliances for providing gas service" [155] are authorized improvements. Solar-generated hot water production and distribution facilities may be installed or otherwise acquired because the statute authorizes "(w)ater, mains, pipes ... and other necessary works and appliances for providing water service" [156].

Active heating and cooling systems can also be financed under this statute, but it should be emphasized that the statute requires the municipality to install its system "in or along its streets" [157]. "Streets" is defined to include "the whole or any part of one or more public streets, alleys, or other places in any municipality, and rights of way owned or held by any municipality for any purpose" [158]. Since active heating and cooling systems are required to be installed on roofs or on retrofit structures located within the property line, it would be necessary for the municipality to obtain and hold easements or "rights of way" for the portion of the private properties upon which the solar system is to be located.

\subsubsection{Housing Mortgage Bonds}

California cities may issue revenue bonds "for the purpose of financing residential rehabilitation" [159] in certain designated "residential rehabilitation areas" [160]. "Residential rehabilitation" includes "construction, reconstruction, renovation, replacement ... repair, betterm ent, equipping . . . or otherwise improving residences." [16 l]. "Residence" includes not only single-family and multiple-family residential units, including condominiums and cooperatives, but also real property improved with a commercial or mixed residential and commercial structure, which the city has determined is an integral part of a residential neighborhood [162].

Under this authority, California cities may finance the inclusion of passive and active structural systems, or other solar energy systems appropriate for residential use, in any of the preceding structures. The systems may be included as part of new construction or retrofitted onto existing structures, so long as they meet the city's architectural and engineering design standards [163] . 


\subsection{FLORIDA}

A Florida statute provides that, "no single family residence shall be constructed within the state unless the plumbing therein is designed to facilitate the future installation of solar water-heating equipment" [164]. There is thus a mandatory state policy supporting active solar heating and cooling systems for residences.

The Florida legislature recognized a need for expanded solar energy utilization when it established the Florida Solar Energy Center to develop solar energy standards: "It is the intent of the legislature ... to encourage the development of an alternative energy capability in the form of incident solar energy" [165].

\subsubsection{General Obligation Bonds}

There are no significant limitations restricting the purposes for which a Florida municipallty may issue general obligation bonds. The Florida Constitution restricts issuance of municipal bonds "payable from ad valorem taxation and maturing morc than twelve months after issuance" in those iesued "to finurice capital projects authorized by law" [166]. A broad Florida statute allows municipalities to issue bonds "to finance the undertaking of any capital or other project" [167] for purposes permitted by the state constitution, "project" being defined as a "governmental undertaking" embracing "any capital expenditure which the governing body of the municipality shall deem to be made for a public purpose" [168]. All types of solar energy development discussed in this paper car thus be financed readily with general obligation bonds.

\subsubsection{Revenue Bonds}

Under tlie Revenue Bond Act of 1953 [169], Florida municipalities may issue revenue bonds to finance a restricted list of "self-liquidating" projects [170], but the list [171] embraces only a few of the solar energy projects under discussion. Processes providing solar-heater witer to agricultural and industrial plants could be financed as "waterworks systems," defined in the statute as "water supply systems (and) water distribution systems" [172]. Biomass gasification plants might be financed as "gas systems . ... (including) works and structures necessary for the production, supply and distribution of gas, manufactured or natural" [173]. Financing of a biomass waste conversion system would be authorized as the financing of a "solid waste disposal system" whereby "solid wastes are burned, buried, composted or any system for such disposal approved by a state pollution control agency" [174].

In addition to the authority provided by the Revenue Bond Act of 1933, Florida municipalities have the power to issue revenue bonds, "to finance the undertaking of any onpital or other project for purposes permitted by the state constitution" [175]. Under these provisions, Florida cities should be able to finance any of the solar energy projects under discussion.

\subsubsection{Industrial Development Bond}

Although the Florida State Constitution forbids any municipality to "lend or use its taxing power or credit to aid any corporation," it affirms that "this shall not prohibit laws authorizing ... the issuance ... by any ... municipality ... (of) revenue bonds to fi- 
nance ... the cost of capital projects for industrial or manufacturing plants to the extent that ... the revenue bonds are payable solely from revenue derived from the sale, operation or leasing of the projects" [176].

Under the Florida Industrial Development Financing Act [177], municipalities are given the power to issue revenue bonds [178] to finance "any capital project comprising an industrial or manufacturing plant or pollution control facility" [179].

Most solar energy facilities under consideration in Florida could be financed with industrial development bonds as long as the facilities aid industrial or manufacturing companies. The statutory definition of "project" is broad and includes "processing plant," thereby authorizing financing of biomass conversion plants. Project also includes "any rehabilitation, improvement, renovation, or enlargement of, or any addition to" any industrial buildings and includes "all appurtenances and facilities incidental thereto, such as ... utilities," thereby clearly authorizing bonds to finance active or passive heating. and cooling systems, industrial process heat systems, photovoltaic solar cells added to new or existing industrial facilities, and other solar-powered electrical generating systems which provide power only for an industrial plant [180].

It is clear that industrial bond financing is not available for the installation of residential solar heating systems.

\subsubsection{Assessment Bonds}

As is the case for general obligation bonds and for revenue bonds, there are no significant limitations restricting the purposes for which a Florida municipality may issue assessment bonds, which are "payable solely from the proceeds of the special assessments levied for an assessable project" [181].

Thus, any type of solar energy facility of special local benefit to assessed properties could be financed under the Florida law relating to assessment bonds.

\subsection{ILLINOIS}

The State of Illinois clearly supports development of solar energy programs. In the Comprehensive Solar Energy Aot of 1877.[182] the lcgialature found:

That it is the responsibility of the State government to encourage the use of alternative renewable energy sources, (and) that it is in the public interest to ... apply incentives for using solar energy. [183]

Moreover, the State legislature declared it "to be the policy of the State of Illinois that the use of solar energy systems should be encouraged" [184]. And the statute provides that "no ... . unit of government shall be barred from funding . . . a solar energy system within the service area of any public energy supplier" [185].

Passive structural systems are apparently excluded from the preceding policy statements, for " '(s)olar energy system' does not include ... (c)omponents of a solar energy system that serve structural, insulating, protective, shading, aesthestic, or other nonsolar energy utilization purposes" [186]. 


\subsubsection{General Obligation Bonds}

The Illino is State Constitution grants all municipalities the power to "incur debt" [187]; in the case of municipalities with populations of 25,000 or less, it is the power "to incur debt except as limited by law" [188]. Illinois statutes also grant municipalities the power to "borrow money on the credit of the corporation for corporate purposes, and issue bonds therefor" [189].

Illino is cities should thus be able to issue general obligation bonds to finance any of the solar energy facilities under discussion. That conclusion is given additional weight by the Illino is statute which provides that municipalities may issue general obligation bonds "(f)or the purpose of acquiring any public utility" [190]. Public utility includes "any plant, equipment, or property" used "for the production, storage, transmission, sale, delivery, or furnishing of cold, heat; light, power, water, or for the conveyance of oil or gas by pipe lines" [191].

Only biomass conversion (other than biomass gasification) may be difficult to bring under the latter statute. It is arguable, however, that biomass conversion products of gasoline and alcohol themselves produce cold, heat, light, and power and that biomass conversion therefore falls within statutory bounds.

As long as waste disposal is considered a proper municipal purpose [192], Illinois cities seeking to finance biomass conversion systems should be able to issue bonds under the authority of the more general statute which allows issuance of bonds "for corporate purposes" [193].

\subsubsection{Revenue Bonds}

The Illinois statute expressly authorizes Illinois municipalities "to pay for the construction of heating plant and system by the issuance and sale of revenue bonds" [194]. An Illinois municipality could thus finance systems generating agricultural and industrial process heat; any cooling provided by these structures would be incidental to the primary purpose of providing heat and should not impair the municipality's ability to provide revenue bond financing.

Illinois law also provides that "(e)very city or village owning and operating its electric light plant and system or its gas plant and system, may pay for improving, enlarging, or extending the plant and system by the issuance and sale of revenue bonds" [195]. By this authority every municipality already providing electricity to its inhabitants may finance solar energy conversion projects which produce electricity; i.e., wind, oceans, solar thermal energy conversion, photovoltaics, and solar-powered satellites. Municipalities should also be able to finance any expansion of preexisting gas systems brought about by addition of a biomass gasification facility.

Thus in Illinois, a city may issue revenue bonds to finance almost any type of solar energy facility, excepting those biomass conversion facilities which do not generate gas or electricity. 


\subsubsection{Industrial Development Bonds}

Under the Industrial Project Revenue Bond Act [196] Illinois statutes authorize any municipality to issue revenue bonds to finance "the acquisition, purchase, construction, reconstruction, improvement, betterment or extension of any industrial project" [197].

Most solar energy projects benefiting an industry could be financed with industrial development bonds in Illinois. The statutory definition of "industrial project" is broad [198] and includes "processing plant," thereby authorizing financing of biomass conversion plants. Because "industrial project" includes "any rehabilitation, improvement, renovation, or enlargement of, or any addition to" any industrial buildings and includes "all appurtenances and facilities incidental thereto such as . . . utilities" [199], industrial bond financing should be available for the following solar energy systems: active and passive structural heating and cooling systems for use in industrial facilities, industrial process heat systems, photovoltaic solar cells incorporated into new or existing industrial buildings, and other solar-powered electrical generating systems which provide power only for an industrial plant.

It is clear, however, that industrial bond financing is not available for the installation of residential solar heating systems.

\subsubsection{Assessment Bonds}

The constitution of the state of Illinois grants municipalities the power "to make local improvements by special assessment" [200]. Illinois statutes provide two major separate procedures wherein cities can authorize assessment bonds to finance the improvements.

One procedure [201] is of limited value to solar energy promoters because "local improvement" is narrowly defined. Of all possible solar energy systems, only the "constructing . . . or repairing of . . . water mains . . gas mains, street lights and all necessary appurtenances thereto" [202] are susceptible to assessment bond financing.

Under this provision a municipality could substitute photovoltaics for conventionally generated electricity to power its street lights. It could finance the construction (or conversion) of its water distribution system to pipe hot water from a small central plant, or it could similarly make the necessary improvements to pipe gas from a biomass gasification plant.

Of more use to solar energy proponents is the second procedure, which authorizes certain municipalities to "make such local improvements as are authorized by law" [203] and to issue assessment bonds [204] . Because "local improvement" is not cefined in the statute, any solar energy facility whose primary benefits are local should be appropriate for finàncing.

It is unlikely that conversion systems such as ocean thermal energy conversion systems and solar-powered satellites will operate cost-effectively on a scale small enough to be considered of local benefit. Neither is biomass production of liquid fuels likely to benefit only a "local" area. But solar production of hot water, biomass gasification and distribution, solar thermal conversion to electricity, photovoltaic generation of electricity, and some wind-power conversion systems seem appropriate for this type of financing, as does installation of active and passive structural systems to provide heating and cooling. 
In Illinois, special service areas can be created in a portion of a municipality to finance any government service or improvement; the bonds so issued are payable from ad valorem taxes levied only in the benefited area [205]. This innovation stems in part from a desire to discourage proliferation of special units of local government that furnish only limited governmental services [206]. Many communities are also turning to special service area projects because of the tax advantages involved. Homeowners may deduct special service area payments as property taxes, but may not deduct the entire amount of special assessments.

\subsubsection{Housing Mortgage Bonds}

Housing mortgage bonds are commonly issued by Illinois municipalities pursuant to constitutional "home rule" powers [207]. Housing mortgage honds would be appropriate for financing activc and passive heating and cooling solar systems for residences under such hom e-rule authority.

\subsection{NEW MEXICO}

The state of New Mexico also clearly supports the development of solar energy programs. In the Solar Energy Development Act [208] the legislature states that it is the purpose of the act "to proinote development and use of solar energy in New Mexico" and "to encourage ... research to discover practicable and feasible methods to harness solar energy to supplement existing but.limited present sources of energy, and development of a vigorous and productive solar energy industrial complex" [209].

\subsubsection{General Obligation Bonds}

In New Mexico, a municipality may issue general obligation bonds "for the purpose of securing funds for" [210] most types of solar energy conversion projects. Biomass waste conversion systems may be acquired and financed as "refuse disposal ... plants" [211]. Biomass gasification plants can be finnneed as "urtificial yus works" [212].

Bonds issued for the approved purpose of "erecting and operating electric works" [213] could finance a wide variety of electrical generating systems ranging from ocean and wind conversion systems through satellites, photovoltaics, and solar thermal conversion systems. Bonds issued for "constructing or purchasing a system for supplying water" [214] will finance a project that distributes hot water from a central source.

Of all the solar energy projects under discussion, only those which produce heating and cooling directly are probably ineligible for general obligation bond financing.

\subsubsection{Revenue Bonds}

In New Mexico, a municipality may issue revenue bonds "for acquiring . . . or otherwise improving a municipal utility" [215]. "Municipal utility" is broadly defined and includes "water facilities, gas facilities or electric facilities owned by a municipality and serving the public" [216]. Thus, cities can finance hot water distribution systems, biomass gasification plants, and the wide variety of electrical generating systems powered by solar energy. 
New Mexico municipalities can also issue revenue bonds for "acquiring . . . (and) improving . . . any revenue producing project" [217], that is, "any municipally owned self-liquidating projects which furnish public services to a municipality and its citizens, including, but not necessarily limited to ... facilities ... for the ... disposal of ... refuse" [218].

As well as producing express authority for revenue bonds issued to finance all types of biomass waste conversion, this statute authorizes bonds for heat-producing facilities that are municipally owned and self-liquidating. Thus, in New Mexico, agricultural and industrial process heat systems, and active and passive structural systems can be financed with revenue bonds to the extent that such systems satisfy a public purpose.

\subsubsection{Industrial Development Bonds}

Under the Industrial Revenue Bond Act [219] New Mexico cities may "issue revenue bonds for the purpose of defraying the cost of acquiring . . . any project . . :" [220] . "Project" is defined broadly, and includes:

any land and building or other improvements thereon ... which shall be suitable for use by: (1) any industry for the manufacturing, processing, or assembling of any agricultural or manufactured products, (2) any commercial enterprise in storing, warehousing, distributing or selling products of agriculture, mining, or industry, but does not include facilities designed for the sale or distribution to the public of electricity, gas, water ... or other services commonly classified as public utilities, and (3) any business in which ... activities of such business involve the supplying of services to the general public or to governmental agencies or to a specific industry or customer. [221]

Bonds cannot be issued under this statute for any solar energy systems which produce electricity, gas, or hot water for public consumption. But the statute is useful for financing solar-generated electricity, heat, gas, or hot water if its distribution is limited to one or more industrial or commercial facilities or service-providing businesses.

Almost all solar energy systems can be appropriate for this type of financing. Biomass waste conversion facilities are "suitable for use" by an "industry for the .... processing ... of any ... manufacturing product" [222]. Active and passive structures, thermal energy conversion systems, photovoltaics, and wind-generated electrical systems fit within the statute.

Only ocean-generated electricity and solar-powered satellites may be impractical if limited to industrial use, and hence may not be financed under the act.

\subsubsection{Assessment Bonds}

In New Mexico, municipalities may issue bonds [223] to finance a restricted list of improvements which they are authorized to construct or otherwise acquire. Included are:

A. A street ... project, including, without limitation, the ... lighting, or in any manner improving all or any part of one (1) or more streets; or B. A . . . water project, including, without limitation, the excavating, laying . . . or in any manner improving all or any part of one (1) or more ... 
water lines. [224]

Under these provisions, cities can use improvement bonds to add photovoltaic solar cells to their street lights, but, unless it is convincing that the work "project" includes generating facilities, they cannot finance more centralized systems for producing electricity, such as wind and solar thermal energy conversion systems.

Similarly, they can finance the laying of pipe for a centralized hot water distribution system, but it is questionable whether they can use improvement bonds to finance its necessary precursor, a hot water production facility.

Improvement bonds are not. available, in New Mexico, to finance solar energy systems which produce gas, liquid fuels, or heat.

\subsection{NEW YORK}

\subsubsection{Gengral Obligatinn Bonde}

The New York Constitution provides: "No ... city ... shall contract any indebtedness except for . . . city . . . purposes" [225]. New York State's Local Finance Law provides that a municipality may contract indebtedness for any municipal object set forth in a long statutory list if "it is authorized by law to expend money for or to accomplish such object or purpose" [226]. The list of permissible objects is so complete that, in the state of New York, the ability of cities to issue general obligation bonds to finance any of the solar energy conversion projects is assured.

Solar-powered electrical generating facilities suoh as ocean therulul energy conversion systems, wind-power installations, solar thermal conversion facilities, photovoltaics, and solar-powered satellites can be financed with general obligation bonds because they fall within the statutory "object" of "electric light and power systems" [227]. Biomass waste conversion facilities can be financed because each can be described as "a plant . . . for the ... treatment . . or disposal of . . . refuse or other solid wastes" [228].

Systems for producing agricultural and industrial process heat and active and passive structural systems may be financed with general obligation bonds when they are added to existing buildings because they fit the statutory object of "installation or reconstruction of a heating ... plant or system in a building when not in connection with the original construction ... of such building" [229]. Similar systems incorporated into new buildings cun be financed because an approved object is the "acquisition or construction of buildings" [230] .

Finally, any system producing steam, sucli as certain agricultural and industrial heat facilities, can be financed because an approved statutory object is the "acquisition (or) construction ... of ... a steam plant or distribution system" [231].

\subsubsection{Revenue Bonds}

The New York statutes authorizing the issuance of revenue bonds are of little help to the promoter of a solar energy conversion project. New York statues provide for a municipality to issue revenue bonds [232] to carry out any "revenue-producing undertaking," 
such being narrowly defined, and limited (for our purposes) to "systems, plants, works ... and properties used or useful in connection with the treatment of water for public and private uses" [233]. Unfortunately, only the production of steam for agricultural and industrial process heat fits cleanly enough into the statutory definition for revenue bond financing to be available. Other types of solar energy projects cannot be financed under the general revenue bond laws in New York.

\subsubsection{Industrial Development Bonds}

Under the New York State Industrial Development Agency Act [234], municipal industrial development agencies created by special act of the legislature [235] may issue revenue bonds [236] to carry out a very broad set of purposes, namely:

to promote, develop, encourage and assist in the acquiring, constructing, reconstructing, improving, maintaining, equipping and furnishing industrial, manufacturing, warehousing, commercial, research and recreation facilities including industrial pollution control facilities. [237]

Because the act's purposes are so broadly stated, most solar energy facilities connected with business enterprises in New York can be financed with industrial development bonds. Bonds can be issued to finance autonomous biomass conversion plants which manufacture liquid fuels or gas, or they can finance biomass conversion facilities which act as a power source for a separate industrial enterprise. Because they can be issued to finance any other solar energy facility which will improve, maintain, equip, or furnish an industrial operation, they can be issued in connection with wind-powered systems, active and passive structural systems in industrial settings, solar thermal energy conversion, and photovoltaics. Even solar energy facilities used in connection with agricultural operations may be financed as "commercial" facilities. Only solar-powered satellites and ocean conversion systems, both of which are inappropriately scaled for industrial operations, may not be financed with industrial development bonds.

Of course, industrial bond financing is not available for the installation of residential solar systems.

\subsubsection{Assessment Bonds}

In New York, a municipality may establish a "water,... lighting ... or refuse and garbage district, ... provide improvements or services" [238] in the assessment district, and issue bonds [239] to finance them.

After establishing a water district, a city may "construct, [and . . . extend ... water works, .... for the purpose of supplying the inhabitants of any water district in such town, with pure and wholesome water for domestic and commercial uses" [240]. It may also lay "water pipes and necessary appurtenances" [24l]. Under this authority, a city is cmpowered to finance central solar-powered heating facilities and a related hot water distribution system.

New York statutes also authorize a city to issue assessment bonds to finance the purchase, installation, maintenance, and provision of electricity to street lighting standards (poles) [242]. Under such authority a city may finance street lights powered by photovoltaic solar cells through the issuance of assessments. 
In New York, a municipality may also use assessment bond financing for a biomass conversion plant because it is authorized to issue assessment bonds to:

(p)rovide for the collection and/or resource recovery or disposition ... of garbage ... rubbish and other waste matter ... and for ... such purposes may construct, operate and maintain refuse resource recovery, disposal or incinerator plants ... and maintain all necessary appliances appurtenant thereto. [243]

Unfortunately; New York municipalities cannot rely on improvement bond laws to finance other solar-powered electrical generating systems, or systems designed to generate heat.

\subsubsection{Mortgage Housing Bonds}

In New York a municipallty may issue serial bonds [244] to provide monies nut of which to issue loans to the owners of certain existing multiple dwellings [245]. Each loan secured by a mortgage on the multiple dwelling and land on which it is situated may be made "in such amounts as may be required for the installation of proper heating facilities" [246].

Accordingly, New York municipalities may issue bonds to finance the installation of active solar heating systems in a large number of multiple dwelling types, including those operated as permanent residences and those operated as residences for transients, including hotels and an extensive list of other facilities.

It is arguable that cities may make these loans only to the owners of those multiple dwellings which lack adequate or safe heating facilities and that they may not make loans to owners who merely wish to replace an adequa te but conventional heating system with a solar energy heating system.

\subsection{SUMMARY}

As is indicated in the following tables, general obligation bond financing of the five selected states is ordinarily available for financing all types of solar facilities; revenue bond financing is broadly available in Florida, Illinois, and New Mexico for solar facility financing but is limited in California to facllitles which convert wastc or produce elertricity and is substantially curtailed in New York; industrial development bond financing is available in each state (except California) for most types of solur facilities, but agricultural he.at processes are often excluded; assessment bond financing varies considerably among the selected states in its application to solar facilities but upuears generally applicable to certain blomass uind photovoltalc fucilities; and where mithority for housing mortgage bonds is provided, its sole application is ordinarily limited to solar facilities improving individual residential structures. 
Table 3-1. SUMMARY OF STATUTORY BOND AUTHORITIES FOR CALIFORNIA

\begin{tabular}{|c|c|c|c|c|}
\hline & \multicolumn{4}{|c|}{ Bond Type } \\
\hline & $\begin{array}{l}\text { General } \\
\text { Obligation }\end{array}$ & Revenue & $\begin{array}{c}\text { Industrial } \\
\text { Development }\end{array}$ & Assessment \\
\hline \multicolumn{5}{|l|}{ Bi om ass } \\
\hline Electricity & Yes & Yes & N/A & Yes \\
\hline Gas & Yes & No & N/A & Yes \\
\hline Liquid Fuel & Yes & Yes & N/A & No \\
\hline Wind & Yes & Yes & N/A & Yes. \\
\hline Ocean & Yes & Yes & N/A & No \\
\hline \multicolumn{5}{|l|}{ Structures } \\
\hline Active & Yes & No & N/A & Yes \\
\hline Passive & Yes & No & N/A & No \\
\hline \multicolumn{5}{|l|}{ Heat } \\
\hline Agricultural & Yes & Hot Water Only & N/A & Hot Water Only \\
\hline Industrial & Yes & Hot Water Only & $\mathrm{N} / \mathrm{A}$ & Hot Water Only \\
\hline Solar Thermal & Yes & Yes & N/A & Yes \\
\hline Photovol taics & Yes & Yes & N/A & Yes \\
\hline Satellițe & Yes & Yes & N/A & No \\
\hline
\end{tabular}


Table 3-2. SUMMARY OF STATUTORY BOND AUTHORITIES FOR FLORIDA

\begin{tabular}{|c|c|c|c|c|c|}
\hline & & \multicolumn{4}{|c|}{ Bond Type } \\
\hline & & $\begin{array}{l}\text { General } \\
\text { Obligation }\end{array}$ & Revenue & $\begin{array}{c}\text { Industrial } \\
\text { Development }\end{array}$ & Assessment \\
\hline \multicolumn{6}{|l|}{ Biomass } \\
\hline Electricity & & Yes & Yes & Yes & Yes \\
\hline Gas & . & Yes & Yes & Yes & Yes \\
\hline Liquid Fuel & & Yes & Yes & Yes & Yes \\
\hline Wind & & Yes & Yes & Yes & Yes \\
\hline Qceann & & Yes & Yes & Ycs & No \\
\hline \multicolumn{6}{|l|}{ Structures } \\
\hline Active & & Yes & Yes & Yes & Yes \\
\hline Passive & & Yes & Yes & Yes & Yes \\
\hline \multicolumn{6}{|l|}{ Heat } \\
\hline Agricultural & & Yes & Yes & No & Yes \\
\hline Industrial & & Yes & Yes & Yes & Yes \\
\hline Solar Thermal & & Yes & Yes & Yes & Yes \\
\hline Photovoltaies & & Yes & Yes & Yes & Yes \\
\hline Satellite & & Yes & Yes & No & No \\
\hline
\end{tabular}


Table 3-3. SUMMARY OF STATUTORY BOND AUTHORITIES FOR ILLINOIS

\begin{tabular}{|c|c|c|c|c|}
\hline \multirow[b]{2}{*}{, } & \multicolumn{4}{|c|}{ Bond Type } \\
\hline & $\begin{array}{c}\text { General } \\
\text { Obligation }\end{array}$ & Revenue & $\begin{array}{c}\text { Industrial } \\
\text { Development }\end{array}$ & Assessment \\
\hline \multicolumn{5}{|l|}{ Bi om ass: } \\
\hline Electricity & Yes & Yes & Yes & Yes \\
\hline Gas & Yes & Yes & Yes & Yes \\
\hline Liquid Fuel & Yes & Yes & Yes & Yes \\
\hline Wind & Yes & Yes & Yes & Yes \\
\hline Ocean & Yes & Yes & No & No \\
\hline \multicolumn{5}{|l|}{ Structures } \\
\hline Active & Yes & Yes & Yes & Yes \\
\hline Passive & Yes & No & Yes & No \\
\hline \multicolumn{5}{|l|}{ Heat } \\
\hline Agricultural & Yes & Yes & No & Hot Water Only \\
\hline Industrial & Yes & Yes & Yes & Hot Water Only \\
\hline Solar Thermal & Yes & Yes & Yes & Yes \\
\hline Photovoltaies & Yes & Yes & Yes & Yes \\
\hline Satellite & Yes & Yes & No & No \\
\hline
\end{tabular}


Table 3-4. SUMMARY OF STATUTORY BOND AUTHORITIES FOR NEW MEXICO

\begin{tabular}{|c|c|c|c|c|}
\hline & \multicolumn{4}{|c|}{ Bond Type } \\
\hline & $\begin{array}{l}\text { General } \\
\text { Obligation }\end{array}$ & Revenue & $\begin{array}{c}\text { Industrial } \\
\text { Development }\end{array}$ & Assessment \\
\hline \multicolumn{5}{|l|}{ Biom ass: } \\
\hline Electricity & Yes & Yes & Yes & No \\
\hline Gas & Yes & Yes & Yes & No \\
\hline Liquid Fuel & Yes. & Yes & Yes & No \\
\hline Wind & Yes & Yes & Yes & No \\
\hline Oceяn & N/A & N/A & N/A & N/A \\
\hline \multicolumn{5}{|l|}{ Structures } \\
\hline Active & No & Yes & Yes & No \\
\hline Passive & No & Yes & Yes & No \\
\hline \multicolumn{5}{|l|}{ Heat } \\
\hline Agricultural & Hot Water Only & Yes & Yes & No \\
\hline Industrial & Hot Water Only & Yes & Yes & No \\
\hline Solar Thermal & Yes & Yes & Yes & No \\
\hline Photovoltaies & Yes & Yes & Yes & Yes \\
\hline Satellite & Yes & Yes & No & No \\
\hline
\end{tabular}


Table 3-5. SUMMARY OF STATUTORY BOND AUTHORITIES FOR NEW YORK

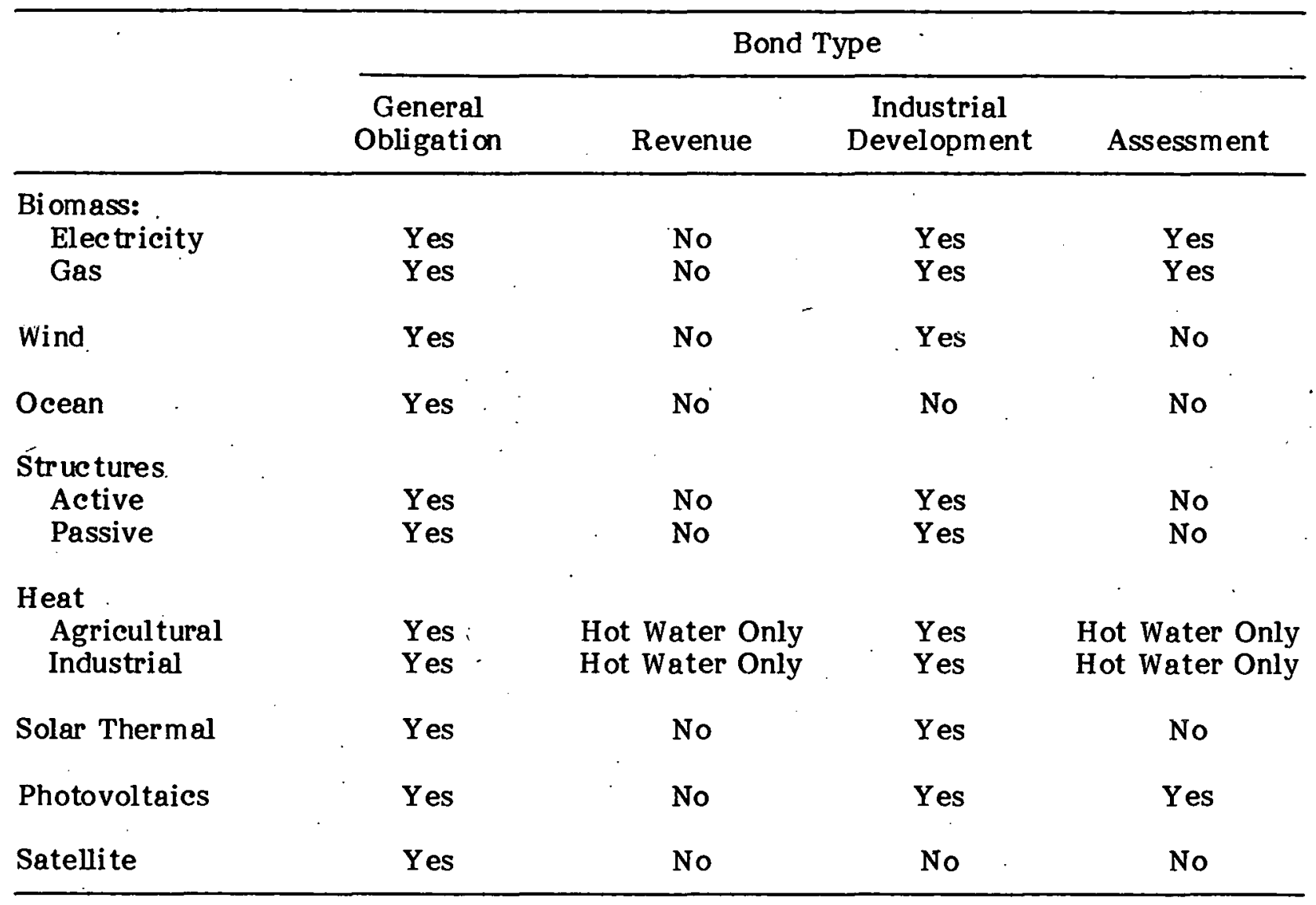


SERI 


\section{SECTION 4.0}

\section{HYPOTHETICAL CASES}

This portion of the report draws attention to the problems and procedures which will be confronted in actually undertaking a municipal bond financing of solar facilities.

The problems and procedures are discussed in terms of hypothetical cases that might be faced by municipalities. It is not the purpose of the hypothetical cases to "solve" each of the problems raised but merely to note issues which will ordinarily be confronted and to discuss approaches to their solution. In reality, political and public opinion problems will be solved under the leadership of municipal leaders; guidance as to financial structure, bond selection, and bond marketing will be provided by the financial consultants to the municipality; and assistance in overcoming legal obstacles will be provided by the municipal attorneys and bond counsel.

The particular hypothetical cases set forth in the following paragraphs were selected to illustrate the application of three distinct types of solar facilities in three different situations. The purpose of such selection is to demonstrate the context in which the legal issues and problems set forth in Sections 2.0 and 3.0 of this report are often raised. The considerations discussed will be similar with respect to each of the types of solar facilities.

\subsection{HYPOTHETICAL CASE 1: ACTIVE SOLAR HEATING SYSTEMS}

The officials of City $M$. are concerned about rising utility costs for residential consumers. They are aware of individually structured active solar heating systems and employ an independent consulting firm experienced and reputable in the application of active solar heating systems to undertake a study concerning the feasibility of widespread application of such systems in the city. Af ter six weeks, the study is issued. It concludes that for the bulk of the homes in the city, active solar systems would be an efficient substitute for existing energy sources for purposes of residential space and hot water heating; in addition, the systems would be effective for certain commercial space and hot water heating; notwithstanding the installation of such systems, conventional energy sources will be required for hackup purposes; the initial cost of such systems would be beyond the means of at least $30 \%$ of the residents of the city; in certain specified locations of the city, old, spacious oak trees would be required to be removed to provide maximum efficiency for the systems; maintenance costs would be minimal; provided initial cost of the system (including installation) did not exceed $\$ \mathrm{X}$ amortized over 20 years (the expected useful life of the systems), said sum plus annual maintenance costs not exceeding. $\$ Y$ would result in a considerable savings in annual energy costs for residential consumers; and for the bulk of homes in the city, neither roof nor retrofit active solar systems would be architecturally displeasing. After extensive review of the report, the governing body of the city determines that it would be desirable to issue municipal bonds to assist in the installation of active solar heating systems within the city. What problems will it encounter? What procedural steps will be required? How should it proceed to overcome the problems and accomplish the procedures? 


\subsubsection{Public or Corporate Purpose}

An early question to be considered is whether the provision, however financed, of solar energy systems to private homes and businesses within the city accomplished a public or corporate purpose of the city or, in the case of a "home rule" city, whether the undertaking could be construed to be a municipal affair of the city. The answer to these questions will require examination of state constitutional provisions and statutes. In those states where cities are specifically authorized to provide "heat" to inhabitants within the city the finding of a public or corporate purpose should not be difficult. Where the state constitutions and statutes are silent, the ability to provide such systems will necessitate a finding, at a minimum, that the well-being of city inhabitants will be enhanced through such systems. Such finding should be evidenced by facts in the record, and the manner by which the well-being of inhabitants is enhanced should be set forth in detail rather than in a conclusionary manner. It is questionable whether savings in cost alone is sufficient to support a finding of public purpose.

\subsubsection{Questions of Property Rights}

Several questions in the area of governmental and individual property rights will undoubtedly be raised. These will include questions of whether the solar systems are to be owned by the city, whether such ownership is possible when the systems include certain structural improvements such as appropriate piping, whether if the city owns the systems it also owns (or should acquire) roof or yard easements both to permit permanent location of the systems as well as access for periodic maintenance, and whether the city and/or the owner of a structure should acquire easements for light to assure continued sunlight for the systems.

These and related questions will require close examination of the general law and bond law upon which the city proposes to rely. If the applicable law requires public ownership of facilities that are publicly financed, arrangements for leasing the equipment tn property owners are perhaps suitable. If the applicable law is silent, sale of the facilities to the uruperty owners may be a desirable method of proceeding.

Maintenance rights of way or easements will depend upon determination of who is to be responsible for maintenance. Access easements for maintenance purposes must be obtained by the city, if the city is to undertake such maintenance.

Questions of property rights will most certainly be raised in the area of acess to sunlight. It is generally established in this country that there is not a prescription easement for sunlight; 1.e., a landowner has no right to receive sunlight over the land of his neighbor. However, easements for light may be arguired or condemined, and land-use planning and zoning ordinunces may be framed by local government entities so as to assure access to sunlight hy certuin structures. In addition, some states have promulgated statutes providing for a full or limited right to light.

In the city's determination to provide active solar heating facilities to properties within the city, the city will be required to give some in-depth thought to the procedure which will assure access to sunlight to all properties using the active solar heating facilities. The city will be faced with several alternatives: 
- limit recipients of solar facilities to structures located in areas where existing zoning regulations assure that such structures will have adequate access to sunlight (e.g., single-story zoning areas);

- revise city zoning ordinances to assure that all structures, or all structures in a specified "solar zone," have access to sunlight;

- require that property owners acquire and record easements to sunlight over neighboring land before providing active solar facilities to structures of such property owners;

- acquire (through negotiation and eminent domain) easements to sunlight to be owned by the city and to benefit properties receiving active solar facilities; or

- employ a combination of these alternatives.

The city must analyze both the disadvantages and advantages of each alternative. It must consider, for example, that existing zoning laws do not ordinarily affect trees and other tall growth but are ordinarily limited to structures; that new zoning laws will not ordinarily affect existing structures; that property owner acquisition of easements could be costly once neighboring landowners learn that they have something of value to sell; and that eminent domain proceedings, if authorized by law, can be both costly and time consuming.

\subsubsection{Selection and Strueturing of Bond Issue}

Because the provision of active solar facilities to individual properties will generate a revenue stream, and because it generally appears equitable to adopt a "users-pay" theory for the provision of solar facilities, a revenue bond issue appears more appropriate than either a general obligation bond or an assessment bond.

A revenue bond issue might be structured so that bond proceeds would be used to purchase a bank of solar equipment including collectors, piping, fans, and storage tanks. Such equipment would be sold under an installment contract arrangement or leased to property owners desiring the equipment. The installment sales payments or the lease rental payments would be used to provide debt service payments on the bonds.

A number of questions will be raised in developing the bond structure for consideration by the financial advisor of the city. A major question will relate to market acceptance of the bond issue. The study prepared by the city will assist in demonstrating the feasibility and efficiency of the systems, but the risks of prospective default on bond payment will require serious consideration. Thus, for example, the following questions must be answered through the bond structure: how can it be assured that the full bank of equipment will be used; i.e., how can it be assured that property owners will actively participate? Advance orders (prior to bond issuance) may be required. Suppose the equipment is not in fact used: should it be resold with sale proceeds to be used for bond payment? Should bond proceeds be used to purchase equipment on an as-needed basis to forestall questions of over-purchase of equipment? Should an early call of bonds be permitted in the event that bond proceeds cannot be fully expended within three years from the date of issue? If equipment is purchased on an as-needed basis, will the resulting cost be so increased as to dilute the feasibility of the program?

Procedures must also be devised to protect against property owner failure to make lease or installment sale payments. If the equipment is taken back, will it have any salvage 
value? What other procedures could be used to assure payment? Will existing law in the state permit, for example, termination of water or other utility service in event of failure to pay? May or should a lien be imposed upon property which may be foreclosed in event of failure to pay? Suppose the solar system is damaged through fire or other risk: should the city require that additional or joint hazard insurance be obtained with respect to the system in an amount sufficient to assure full repayment to the city?

Repayment of the portion of the bond principal relating to issuance costs must also be assured. Issuance costs may include such items as attorneys' and advisors' fees, underwriters discount, and the like. Certain debt service reserve funds and possibly capitalized interest will be required. These may or may not be funded with bond proceeds. Obviously as the bond principal increases, the amount to be paid by the users receiving solar systems will increase, at least to the extent that investment earnings on retained bond proceeds do not provide for bond repayment. Once again, the question of costeff ectiveness will be raised.

In addition, the bond law pursuant to which the bonds are to be issued must be examined. If the only available bond law is limited, for example, to the provision of facilities for the generation of electricity, it will not be available for the financing of the program in question. If the city is a home-rule city, it may issue bonds under a procedure ordinance in the supposition that the undertaking of the program is a municipal affair. If the city is not a home-rule city, state amendment to the bond law may be required. This, of course, is a time consuming and not always successful undertaking.

If an applicable bond law is available for the program, its required procedures must be examined. In particular, it must be determined whether an election will be necessary. Ordinarily, an election will be required and may be desirable in any event to assure wide public acceptance of the program.

Finally, tax considerations with respect to the bond issued must be examined. The facilities to be financed will not automatically be exempt since they do not furnish gas or electricity. If more than $25 \%$ of the hond proceeds will be used for facilities placeed upon commercial or other business structures (including homes used for business purposes), the size of the bond issue (taking into account qualifying capital expenditures) must be kept under $\$ 10$ million, or (if it is not desirable to take into account related capital expenditures) under $\$ 1$ million. If less than $25 \%$ of the bond proceeds will be used for commercial facilities, the amount of the bond issue is unlimited.

\subsubsection{Acquisition, Installation, and Maintenance of Equipment}

Ordinarily, public bidding law will apply to acquisition of the equipment. Spccifications must be carefully drawn to assure that sound and efficient equipment is obtained. In addilion, the question of whether installation should be by the contractor or by the city will be raised. The most efficient installation method must be selected taking into account experience, equipment guarantees, protection against property damage, and the like.

A closely related question will concern maintenance, but here the selection will probably be between the city and the property owner. Maintenance by the city would ordinarily be preferable to assure skilled and experienced maintenance as well as continuously functioning systems. Maintenance by the city will in turn require the selection of a system of maintenance charges either imposed on a regular basis (in which case further revenue may be generated for bond repayment) or on an as-needed basis. 


\subsubsection{Coordination with Competing Utilities}

If the city does not operate a gas or electric utility system and if widespread displacement of existing gas and electric services will result from the undertaking of the active solar system program by the city, serious questions may be raised by competing utility companies. Their services will be continued to be needed for backup purposes, but such alternate use may adversely affect the existing actual use of their overall facilities, which may be structured on a demand basis. Will there be a potential consequent increase in the charges for existing utility services? Would the existing utility be amendable to entering into an agreement with the city acting on behalf of existing solar users to forestall such an increase?

In addition, the city must consider whether the adverse effect upon the existing utility will be so serious as to cause the utility to raise antitrust claims. In most instances, the city will have an unequivocal right to enter into the solar utility business in competition with the existing utility, even if it has provided a franchise to the utility. However, the city should avoid actions forbidden by the Sherman Act.

\subsubsection{Environmental Problems}

Finally, the city must weigh (whether or not required by law in the particular state) the overall social benefit of the program against any environmental damage which might be caused by the program. Eliminating spacious oak trees in a residential area of the city, for example, may be undesirable. Problems of glare, increased temperature, and architectural desirability should also be taken into account. In most cases, adverse environmental effects should be minimal; but it will, of course, be a matter to be determined on a case-by-case basis.

\subsection{HYPOTHETICAL CASE 2: BIOMASS CONVERSION SYSTEM}

The officials of City $\mathrm{N}$ are.approached by an entrepreneur who advocates the installation of a pyrolizer, the first of its kind, to dispose of municipal wastes through high-temperature burning without oxygen. Such process will produce a natural gas which may be used to operate a turbine for the production of electricity. As by-products, the process produces marketable metals and an unusable ash. The officials of the city are skeptical about feasibility of the process and request the entrepreneur to demonstrate feasibility. The entrepreneur, using personal financial resources, puts the process into operation at another smaller location; and two years later, returns to the city with a full report demonstrating the feasibility, efficiency, and benefits of the process. The city owns a municipal waste disposal site which is almost filled to capacity, and city officials desire to put the process into operation using municipal bonds as the financing vehicle. What problems will it encounter? What procedural steps will be required to accomplish the project?

\subsubsection{Seleetion of Bond Issue}

The project will be of benefit to the entire city in that its first and primary purpose will be the disposal of solid waste generated by city inhabitants. As a secondary use it will produce electricity which may be distributed to city inhabitants. A general obligation 
bond would undoubtedly be the most suitable type of bond issue since property taxes would provide the ultimate source of repayment, and since the interest rate will probably be lower than for another type of bond issue. If, however, it is believed that two-thirds of the voters in an election may not approve the issue, revenue bond financing may provide a suitable alternative. An election may also be required for the revenue bond; but, ordinarily, revenue bonds may be approved by only a majority vote rather than by a two-thirds vote.

The major source of revenues for bond repayment would be a fee for solid waste disposal. In addition, revenues will be had from the sale of electricity to the local utility supplier, whether such is a privately owned utility or the city itself.

Financial advice will be required in the structuring and marketing of the bond issue. A debt service reserve fund and, possibly, capitalized interest may be required to be funded from bond proceeds. In addition, issuance costs will ordinarlly be paid from bond proceeds. The waste disposal fees and electricity sale charges must be established àt a level sufficient for borid debt service, and bond reserves must be adequate to provide for payment in the event of default.

\subsubsection{Assurance of Waste Disposal}

The prospects of default will center primarily around the question of whether solid waste will be continuously supplied on an adequate basis to provide for efficient operation of the pyrolizer. The greater the monopoly of the city over disposal of waste of its inhabitants, the less will be the prospect of default on the bonds. Sherman Act prohibited practices must, however, be avoided.

A city that operates its own solid waste transportation system will be more able to control the flow of solid waste to the city-owned disposal facility. If the city does not own a solid waste transportation system, negotiation with franchise holders to assure full use of the city disposal facility will be nccc3sary. Surh negotiations must be completed prior to bond issuance.

In considering the sufficiency of the generated waste, the city will be required to review any long-term solid waste disposal plans relating to the area in which the city is located. These may include county and, possibly, state solid waste disposal plans. Plan amendment may be necessary in some instances. Finally, in considering the sufficiency of the generuted waste, the city will be required to examine population and disposal trends. If population studies indicate a declining population, it is likely that generated waste will decline. If disposal trends indicate likely development of home operated waste units, again the generation of waste for municipal disposal units may decline.

The outcome of the city's studles concerning waste generation will seriously affect the marketability of, and interest rate for, the city's revenue bonds. The bond market will seek a continuous, controlled supply of solid waste, with minimal risk of solid waste diversion, in determining whether it will accept the bond issue.

\subsubsection{Outlet for Electricity}

The pyrolizer will produce electricity as a major end product. Of course, a major determination by the city will be the outlet for such electricity. Who will purchase it and for 
what price? Long-term contracts extending for the full bond term must be negotiated and executed prior to bond issuance. The price at which the electricity is sold must, of course, be competitive; but, the revenue generated must be sufficient (with the proceeds of waste disposal fees) to provide for bond security and repayment.

\subsubsection{Installation and Operation}

Notwithstanding the fact that a particular entrepreneur has approached the city with a particular pyrolizer, public bidding on the purchase and installation of the system may be required. The specifications will require careful formulation to assure that the city obtains the pyrolizer it desires and that the pyrolizer is installed in an efficient and effective manner. The competitive bidding should be completed prior to bond issuance to assure that the city obtains the process it desires at a cost which is feasible. In addition, the process will require continuous and skilled operation. The city may not have the expertise necessary to provide for such operation and may wish to enter into an operating contract for such purposes. Or it may wish to employ skilled assistance as a part of city staff. Operation methods will again require determination prior to bond issuance in order that the bond market may be assured of competent and continuous operation.

\subsubsection{Tax Problems}

If the facility financed in the hypothetical case under consideration would be termed an industrial development bond, because of the use of the electricity in the business of a privately owned utility, or because the city desires to enter into a long-term contract for operation of the system with a profitmaking buisness, it should be possible to find that the facility financed is an exempt activity as "solid waste disposal facility." This will primarily depend upon a finding that the solid waste constitutes at least $65 \%$, by weight or volume, of the total materials introduced into the process.

\subsection{HYPOTHETICAL CASE 3: WIND POWER FOR AN INDUSTRIAL PLANT}

City $\mathrm{O}$ is approached by XYZ Manufacturing Company, which explains that while it has heretofore employed natural gas for the purpose of satisfying its energy needs, the price of natural gas has increased exorbitantly; in addition, the natural gas suppliers are predicting that natural gas supplies may be terminated entirely in the near future. The company therefore wishes to substitute wind-power as an energy source for the company. A feasibility study demonstrating the efficiency of a particular wind-power system for the company has been produced. The system includes electrical storage facilities, and the feasibility study makes it clear that the wind-power system envisioned will satisfy all of the energy needs of the company indefinitely. The wind-power system will cost $\$ 2$ million. XYZ Manufacturing Company is the largest employer in City O; if the company should close, the unemployment rate in the city would increase dramatically and severe economic distress would be caused throughout the town. The city is therefore desirous of assisting the company through the issuance of municipal bonds. What problems might it encounter, and what procedures will be necessitated?

\subsubsection{Seleetion of Type of Bond}

The only feasible type of bond for the project envisioned would be an industrial develop- 
ment bond. The industrial development bond law of the state will require scrutiny to determine applicable procedures and potential stumbling blocks. Of concern will be whether the purposes for which the bond law may be used in the state to cover the project in question. For example, is the bond law limited to projects which create new employment? Is it limited only to certain types of industries or companies of a certain financial worth or having a certain investment grade rating on its indebtedness? Is it limited only to certain types of facilities? In addition, what procedural limitations does it contain? For example, does it require that an election be held if the bond issuer is the city? Does it require a public hearing or a certain vote of the governing body? Does it require the bonds to be "self-liquidating" so that any general fund security by the city is avoided? Again, what limitations does it contain upon use of bond proceeds? Does it prohibit funding of reserves? capitalized interest? working capital?

Finally, the public purpose behind the bond law should be examined. If, for example, the company to be aided by the bond project has already commenced the project prior to approaching the city, the public purpose behind the bond law may not be achieved.

\subsubsection{Tax Considorations}

In the hypothetical situation, the bond proceeds are to be used in the trade or business of a profit-making person. There is no question therefore as to whether an industrial development bond for tax purposes is involved. On the other hand, the facilities to be financed are for the purpose of generating electricity; the interest on the bonds will be exempt if the following four questions are answered in the affirmative:

1. Do the facilities constitute land or property of a character subject to the allowance for depreciation under Section 167 of the Internal Revenue Code?

2. Are the facilities used to produce, collect, generate, transmit, store, distribute, or convey electric energy?

3. Are the facilities used in the trade or business of furnishing electricity?

4. Are the facilities part of a system providing service to the general public of one or more cities but in no event more than one city and one county or two counties?

In the hypothetical case under discussion, neither question (3) nor question (4) may be answered in the affirmative; hence, the interest on the bonds will not be exempt as for the purpose of financing an exempt activity.

Since the bonds do not qualify as bonds for financing an exempt activity, the interest on the bonds will be exempt from income taxes only if the bonds qualify as a "small issue." The bonds will qualify as a small issue under $\$ 10$ million only if the sum of the face amount of the bonds plus the capital expenditures made by XYZ Manufacturing Company (assuming the company is the principal user of the manufacturing plant and the windmill). with respect to the manufacturing plant and windmill in the 6-yr period extending from three years prior to three years following bond issuance is $\$ 10$ milliion or less.

\subsubsection{Financing Structure}

The financing structure will depend, in part, upon the provisions of the industrial devel- 
opment bond law in question. In the hypothetical situation under discussion, an appropriate structure would entail a ground lease from the company to the city of the land upon which the windmill (and related equipment) is to be located; the use of bond proceeds for construction of the windmill with disbursement of proceeds on a periodic basis by the bond trustee to a company contractor who constructs and installs the windmill; the lease back to the company by the city of the land. with the completed windmill thereon, and the payment of lease rentals by the company to the city in an amount sufficient to pay debt service on the bonds. In lieu of the lease arrangement, an installment sale arrangement could be used if determined to be more appropriate for purposes of the company.

\subsubsection{Public Opinion and Environmental Concerns}

Initial adverse public opinion is frequently a difficult problem in industrial development bond financing. In any given case, it will be important to make it clear (if true) that the city's taxing power does not provide security for the bonds. Where the beneficial effect upon local economy of the assistance to the company to be aided is clear, adverse public opinion will ordinarily diminish.

Adverse environmental effects must be examined in any given case. The windmill to be financed in the hypothetical situation, for example, may be aesthetically displeasing (depending in part upon its location in relation to other industrial structures). The social benefit of the project then must be balanced against the environmental harm caused by the project.

\subsection{CASE CONCLUSIONS}

In the three hypothetical situations discussed, the facts assume that the solar facility to be financed is technologically feasible and cost-effective. The importance of this assumption in any given municipal financing cannot be underestimated. It is the market that is the final arbiter of the financing. If the market is not convinced (through studies or other means) that the project to be financed is feasible, bonds to finance the project may not be marketable. 
SEPI 


\section{SECTION 5.0}

\section{CONCLUSION}

It should be obvious from this report that there appear to be no major legal obstacles to the use of municipal bond financing for solar energy facilities, given the stated caveats regarding purpose of the facilities. Not all solar facilities under all conditions may be able to be financed by all types of municipal bonds, but in general, most solar facilities can be structured in such a way as to allow for municipal bond financing. The key to the use of such financing will then lie in the realm of public demand for and acceptance of solar energy systems for community purposes, which in turn will depend on the existence of technical and economic feasibility of the systems involved. 
SझR1) 


\section{SECTION 6.0}

\section{REFERENCES}

1. Town of Gila Bend v. Walled Lake Door Co., 107 Ariz. 545, 490 P.2d 551 (1971).

2. McConnell v. Lebanon, 203 Tenn. 498, 314 S.W.2d 12 (1958). Citizen Sav. \& Loan Assoc. v. Topeka; 87 U.S. (20 W all) 655, 22L. Ed. 455 (1874).

3. Green v. Frazier, 253 U.S. 233, 646 L.Ed 878, 40 S.Ct. 49.9(1920).

4. Keeter v. Lake Lure, 264 N.C. 252, 141 S.E.2d 634 (1965).

5. Beardsley v. City of Darlington, 14 Wis. 2d 369, 111 NW.2d 184 (1961).

6. Clifford v. City of Cheyenne, 487 P.2d 1325, 1329 (Wyo. 1971).

7. Veterans' Welf are Bd. v. Jordan, 189 Cal. 124, 208 P. 284 (1922); State v. Daytona Beach Racing \& Recreational Facilities, 89 So.2d 34 (Fla. 1956).

8. See the following articles for a discussion of the issue: "Legal Limitations on Public Inducements to Industrial Relocation," 59 Col. L. R. 618, "Incentives to Industrial Relocation; The Municipal Industrial Bond Plans," 66 Harv. L. Rev. 898.

9. Two recent housing issues involving national attention are the $\$ 100$ million SingleFamily Mortgage Revenue Bonds, 1978 Series A, of the City of Chicago, nlinois and the $\$ 50$ million Single-Family Mortgage Revenue Bonds, 1978 Series A, of the City and County of Denver, CO.

10. Wheelon v. South Dakota Land Settlement Bd., 43 S.D. 551, 181 N.W. 359 (1921).

11. Laughlin v. City of Portland, 111 Me. 486, 90 A. 318, at 322, (1914).

12. Wells v. Salina, 119 N.Y. 280,23 N.E. 870 (1890).

13. Bond v. Cow an, 272 Mich. 296, 261 N.W. 331 (1935).

14. Consumers Public Power District v. Boettcher, 138 Neb. 22, 291 N.W. 709, 717 (1940).

15. Common Council v. Engel, 187 Mich. 88, 153 N.W. 537 (1915).

16. Mayor and Board of Aldermen v. Delmas, 108 Miss. 91, 66 So. 329 (1914); City of Long Beach v. Boynton, 17 Cal. App. 290, 119 p. 677 (1911).

17. See for example, City of Grass Valley v. Walkinshaw, 34 Cal.2d 595, 212 P.2d 894 (1949) pertaining to California home-rule provisions, and Illinois Constitution Article 7, \$6 (1970) which grants home-rule status to any municipality that has a population of more than 25,000 and to those with lesser populations which elect by referendum to become home-rule units.

18. Kanellos v. County of Cook, 53 Ml. 2d 161, 290 N.E. 2d 240 (1970); for discussion see Froehlich, "Illinois Home-Rule in the Courts," 66 nl. B. J. 320 (1975).

19. City of Lexington v. Thompson, $113 \mathrm{Ky} .540,68 \mathrm{S.W} .477$ (1902), City of Portland v. Weleh, 154 Ore. 286. 59 P.2d 228, (1986) Consumers' Coal Co. v. City of Lincoln, 109 Neb. 51, 189 N.W. 643 (1922). 
20. Nashville Elec. Service v. Luna, 185 Tenn.175, 204 S.W.2d 529 (1947) Dairy Belle Farms v. Brock, 97 Cal. App.2d 146, 217 P.2d 704 (1950).

21. Shean v. Edmonds, 89 Cal. App.2d 315, 200 P.2d 879 (1948), Mueller v. Thompson 149 Wisc. 488,137 N.W. 20 (1912).

22. State v. City of Milwaukie, 231 Ore. 473, 373 P.2d 680 (1962), City of Fond du Lac v. Town of Empire, 273 Wisc. 333, 77 N.W.2d 699 (1915).

23. Burns v. Linn, 49 Okla. 526, 153 P. 826 (1915).

24. Compare City of Tulsa v. Dabney, 133 Okla.54, 270 P.1112 (1928) and State v. City of Fort Pierce (Fla.) 88 So.2d 135 (1956).

25. See, e.g., City of South Pasadena v. Pasadena Land \& Water Co. 152 Cal.579, 93 P. 490 (1903).

26. See, e.g., City of Grass Valley v. Walkinshaw, 34 C2d 595, 212 P.2d 894 (1949) where the court held that a limitation upon the property tax rate set forth in the City charter did not affect the jower lo issue bonds pursuant to the charter where the tax rate required to repay the bonds would exceed the charter tax rate limit.

27. 98 S.Ct. 1123 .

28. 317 U.S. 341 , at 351-52 (1943).

29. Louisiana, id. 98 S.Ct. 1123 at page 1134.

30. Id. at 1137 .

31. See, e.g., DeLoach v. Scheper, 188 S.C. 21,198 S.E. 409 (1938), where the court states in a positive manner, "General obligation bonds mean but one thing. They are bonds payable from an unlimited general ad valorem tax on all taxable property."

32. Schureman v. State Highway Comm'n, 377 Mich. 609, 141 N.W.2d 62 (1966); cf. Alan v. County of Wayne, 388 Mich. 210,200 N.W.2d 628 (1972); adhered to, reh. denied, 388 Mich. 626,202 N.W.2d 277 (197?), where it was held that revenue bonds issued by an authority were in fact unlimited tax bonds and general direct obligations of a county because they were secured in part by a full faith and credit pledge of the county to pay rent on the facilities financed.

33. City of Eugene v. Willamette Valley Co., 52 Ore. 490, 97 P. 817 (1908); Ramsey v. Cameron, 245 S.C. 189, 139 S.E.2d 765 (1965); Richards v. Clark County, 197 Wash. 249, 84 P.2d 1009 (1938).

34. Port of New York Authority v. Baker, Watts \& Cn., 392 F.2 497 (D.C. Cir. 1968).

35. Jones v. Hammer, 145 Wash. 525, 255 P. 955 (1927).

36. Rivers v. City of Ownesboro, 287 S.W.2d 15l (Ky. 1956); Port of New York Authority v. Baker, Watt \& Cu., supra nole 34.

37. Little River Bank \& Trust Co. v. Johnson, 105 Fla. 212, 141 So. 141 (1932); City of DeLand v. State ex.rel. Bond Realization Corp., 120 Fla. 402, 162 So. 892 (1935) (special assessments but full faith and credit also pledged and the court noted at page 895 that, "If negotiable securities arc phrased as a general obligation of the municipality, although they may contain provisions for their payment from a special fund or tax upon specific property, as in the case of local improvement bonds the authorities are quite uniform in holding that, upon the exhaustion of such special fund of tax levy, the general revenues of the municipality can be drawn 
upon to meet these obligations.") But cf. Zimmerman v. Town of New Martinsville, 117 W.Va. 752, 188 S.E. 124 (1936), where the court limited bond service to revenues from property tax levies, and Central Illinois Public Service Co. v. Miller, 42 Ill.2d 542, 248 N.E. 2d 89 (1969), where the constitution requires the levy of an annual tax to debts. Note also, United States v. City of New Orleans, 98 U.S. 281 (1878), a leading case which holds that, even though the bonds involved a pledge of railroad company stock, the bondholder could proceeds directly against the issuing entity without first exhausting the alternative course of payment; i.e., the stock.

38. Walton v. Carter, 337 S.W.2d 674, 677 (Ky. 1960).

39. Clay County v. United States, 115 U.S. 616 (1885).

40. White v. Mayor of City of Decatur, 119 Ala. 746, 23 So.999 (1898).

41. Hammond v. Place, 116 Mich. 628, 74 N.W. 1002, 1003 (1898).

42. Village of Kent v. United States ex rel. Dana, 113 F. 232 (6th Cir. 1902). The court's conclusion is, however, less than satisfactory, for while it emphasizes on the one hand that ". . . city may be required to levy a tax if it refuses to do so" (113F. at 240), it concludes on the other,". . . so long as the electors have it within their power to levy additional taxes, the dire consequences predicated from the appropriation of the general revenue to debt-paying purposes cannot follow, unless such result shall flow from the refusal of the voters to exercise the power clearly conferred by statute." Ibid.

43. Beaulieu \& Allen v. Gity of Pleasant Hill, 14 F.222 (C.C.W.D.Mo. 1882).

44. Ralls County Court v. United States, 105 U.S. 733 (1881); Mayor and Aldermen v. United States ex rel. Jackson, 113 U.S. 332 (1885).

45. See State ex rel. First National Bank v. Melville, 149 Ore. 532, 41 P.2d 1071, (1935), and cases and texts cited therein.

46. Id. at 1076 .

47. But see City of Belton v. Harris Trust \& Savings Bank, 273 S.W. 914 (Tx. Civ. App. 1925), where the court held that the adoption by reference by a city charter of certain state statutes containing tax limitations resulted in a limitation upon bonded indebtedness to the amount of permitted taxation.

48. See, e.g., article XVI, $\$ 18$ of the California Constitution, providing:

No county, city, town, township, board of education or school district, shall incur any indebtedness or liability in any manner or for any purposes exceeding in any year the income and revenue provided for such year, without the assent of two-thirds of the qualified electors thereof. ...

49. See, e.g., article VII, $\$ 12$ of the Florida Constitution, providing:

Counties, school districts, municipalities, special districts, and local governmental bodies with taxing powers may issue bonds, certificates of indebtedness or any form of tax anticipation certificates, payable from ad valorem taxation and maturing more than 12 months after issuance only:

(a) to finance or refinance capital projects authorized by law and only when approved by vote of the electors who are owners of freeholds therein not wholly exempt from taxation; or 
(b) to refund outstanding bonds and interest and -redemption premium thereon at a lower net average interest cost rate.

50. See, e.g., article III, $\$ 52(\mathrm{~b})$ of the Texas Constitution, providing:

Under Legislative provision. . . any political subdivision of the state. . . upon a vote of two-thirds majority. . .may issue bonds or otherwise lend its credit in any amount not to exceed one-fourth of the assessed valuation of the real property of such. . .territory. . . for the following purposes to wit:

1)The improvement of rivers. . .

2)The construction and maintenance of pools. . .

3 ) The construction ... of . . . roads ...

51 . See discussion under revenue bonds, infra.

52. John Hancock Mutural Life Insurance Co. v. City of Huron, 80 F.652 (C.C.A. South Dakota 1897), uff'd., 100 F. 1001 (8th Cir. 19nn); Millsaps v. City of Terrell, $60 \mathrm{~F}$. 193 (5th Cir. 1894); Heyburn v. Security Savings \& Trust Co., 55 Idaho 732, 49 P.2d 258 (1935); Board of Comm'rs v. MeClellan, 164 La. 808, 114 So. 691 (1927), but holder of void bonds allowed to recover debt; Post v. Kendall County Sup'rs, 105 U.S. 667 (1881).

53. See, e.g., Webster Realty Company v. City of Fort Dodge, 174 N.W.2d 413, 421 (1970), where the court concluded that a statutory limitation upon municipal debts "for general and ordinary purposes" did not encompass general obligation bonds of a city issued for urban renewal objectives, since "Urban renewal laws are extraordinary in policy and purpose."

54. Dalton v. State Property \& Bldg. Comm'n, 304 S.W.2d 342 (Ky. 1957); Schureman v. State Highway Comm'n., 337 Mich. 609, 141 N.W.2d 62 (1966); Ziegler v. Witherspoon, 331 Mich. 337, 49 N.W.2d 318 (1951); State ex rel. Consumers Public Power Dist. v. Boettcher, 138 Neb. 22, 291 N.W. 709 (1940); Britt v. City of Wilmington, 236 N.C. 446, 73 S.E.2d (1952).

55. Castle Farms Dairy Stores v. Lexington Market Authority, 193 Md. 472, 67 A.2d 490 (1949).

56. MeKinney v. City of Owensboro, 305 Ky. 253, 203 S.W.2d 24 (1937).

57. Texsan Service Co. v. City of Nixon, 158 S.W.2d 88 (Tex. Civ. App. 1942).

58. Wayland v. Snapp, 334 S.W.2d 633 (Ark. 1960).

59. Ziegler v. Witherspoon, supra note 56 .

60. "Debt" means: "A sum of money due by certain and express agreement." Black's Law Dirtinnary 525 (3d cd. 1044). "Obligatiun" Illeuns: "A legal duty, by which a person is bound to do or not to do a certain thing." Id. at 1272.

61. Port of New York Authority v. Baker, Watts \& Co., 392 F.2d 497 (D.C. Cir. 1968).

62. State ex rel. Hammermill Paper Co. v. LaPlante, 205 N.W.2d 58, 784 Wis.2d 32 (1973); Goreham v. Des Moines Metropolitan Solid Waste Agency, 179 N.W.2d 449 (Iowa 1970); Newberry v. City of Andalusia, 257 Alà. 49, 37 So.2d 629 (1952); City of Glendale v. Chapman, 108 Cal. App.2d 74, 238 P.2d 162 (1952); Young v. City of Ann Arbor, 267 Mich. 255, 255 N.W. 579 (1934); Mann v. Terre Haut, 240 Ind. 245, 163 N.E.2d 577 (1960).

63. Douglass v. Iowa City, 218 N.W.2d 908 (Iowa 1974); City of Bowling Green v. Kirby, 
220 Ky, 839, 295 S.W. 1004 (1927); Farmers State Bank v. Conrad, 100 Mont. 415, 47.P.2d 853 (1935).

64. State v. City of Lakeland, 154 Fla. 137, 16 So. 2d 924 (1944); Little River Bank \& Trust v. Johnson, 105 Fla. 212, 141 So. 141 (1932); Wright v. City of Palmer, 468 P.2d 326 (Alaska 1970).

65. Alan v. County of Wayne, 388 Mich. 210, 200 N.W.2d 628 (1972); but see, City of Mont clair v. Donaldson, 205 Cal.App.2d 201, 22 Cal.Rptr. 842 (1962).

66. Specific statutory authority appears to be required if the facility proposed to be leased is characterized at "governmental" (see, Buckhout v. City of Newport, 68 R.I. 280, 27 A.2d 317 (1942); City of Bessemer v. Huey, 247 Ala. 12, 22 So.2d 325 (1945); Derr v. Fairview, 121 Okla. 23, 247 P. 45 (1926), but lacking specific statute, authority to lease property characterized as "proprietary" will be implied (see, Bailey v. City of Philadephia, $184 \mathrm{~Pa} .594,39$ A.494 (1898); S.D. Realty Co. v. Sewerage Comm'n, 15 Wis.2d 15, 112 N.W.2d 177 (1961).

67. City of Edwardsville v. Jenkins, 376 Ill. 327, 33 N.E.2d 598 (1941); City of Fergus Falls v. Edison, 74 Minn. 121, 102 N.W. 218 (1905).

68. Simons v. City Council of Charleston, 181 S.C. 353, 187 S.E. 545 (1936). Cf. Scott v. City of Shreveport, 20 F. 714 (C.C.W.D. La. 1884).

69. Webster v. North Orange Memorial Hospital Tax Dist., 187 So.2d 37 (Fla. 1966); Doyle v. Rossen, 229 S.C. 67, 91 S.E.2d 887 (1957); In re Local Improvement Distr. No. 1 of Water Dist. No. 49 King County, 195 Wash. 439, 81 P.2d 289 (1938).

70. Guthrie v. City of Mesa, 47 Ariz. 336, 56 P.2d 655 (1936); Crawford v. City of Prescott, 52 Ariz. 47 1, 83 P.2d 789 (1938).

71. La Mesa v. Freeman, 137 Cal.App.2d 813, 291 P.2d 103 (1955).

72. Douglass v. Iowa City, 218 N.W.2d 908 (Iowa 1974).

73. Chamberlain v. City of Mobile, 243 Ala. 662, 11 So.2d 724 (1943).

74. City of Harrison v. Bráswell, 209 Ark. 1094, 194 S.W.2d 12 (1946).

75. 15 McQuillan, The Law of Municipal Corporations, section 43.131 (3rd ed. 1968).

76. State v. City of Lakeland, 154 Fla. 137, 16 So.2d 924, 925 (1944); Ohio Power Co. v. Craig, 50 Ohio App. 239, 197 N.E. 820 (1935).

77. 59 Cal. App. 200, 209, 210, p. 536, 540 (1922). See also Irish v. Hahn, 208 Cal. 339, 281 P. 385 (1925); Whiltier v. City of Dixon, 24 Cal. 2d.664, 151 P.2d 5 (1944); City of Edwardsville v. Jenkins, 376 Ill, 327,33 N.E.2d 598 (1941); Hinman v. Temple,-133 Neb. 268, 274 N.W. 605 (1937).

78. And so, assessments for the following improvements have not been upheld in the circumstances considered: bridges and viaducts, City of Waukegan v. DeWolf, 258 Ill. 374, 101 N.E. 532 (1913), City of Chicago Heights v. Walls, $319 \mathrm{Ill}, 411,150$ N.E. 241 (1926), Himan v. Temple, 133 Neb. 268, 274 N.W. 605 (1937), power houses and generating plants, Ewart v. Village of Western Springs, 180 Ill. 318, 54 N.E. 478 (1899); convention halls and auditoriums, Ruel v. Rapid City, 84 S.D. 79, 167 N.W. 2d 541 (1969), Lipscomb v. Lenon, 169 Ark. 610, 276 S.W. 367 (1925).

79. Clark v. City of Royal Oak, 325 Mich. 298, 38.N.W.2d 413 (1949).

80. Brock v. Lamke, 51 Haw. 175, 455 P.2d 1, 3 (1969). Sée also, Hildredth v. City of Longmont, 47 Colo. 79, 105 P. 107, 114 (1909); Kankakee Stone \& Lime Co. v. City 
of Kankakee, 128 Ill. 173, 20 N.E. 670 (1889).

81. Driscoll v. North Bridge, 210 Mass. 151, 96 N.E. 59 (1911).

82. Duke v. City of Anniston, 5 Ala.App. 34, 60 So. 447 (1912); Town of Fort Lupton v. Union Pac. R.R, 156 Colo. 352, 399 P.2d 248 (1956); Finlayson v. Town of Montecello, 137 Fla. 697, 189 So. 21 (1939); Jardine v. Borough of Rumson, 30 N.J. Super. 509, 105 A.2d 420 (1954); Alf. v. Flick, l Ohio Misc. 37, 204 N.E.2d 418 (1962); Bragdon v. City of Muskogee, 133 Okla. 225, 271 P. 1006 (1928); Fisher v. City of Astoria, 126 Ore. 268, 269 P. 853 (1928); In re Taylor Ave. Assessment, 147 Wash. 214, 270 P. 827 (1928).

83. Martin v. District of Columbia, 205 U.S. 135 (1907).

84. Kansas City Souther Ry. v. Road Improvement Dist. No. 3, 266 U.S. 379 (1924).

85. Gast Realty \& Investment Co. v. Schneider Granite Co., 240 U.S. 55 (1916); Houck v. Little River Drainage Dist., 239 U.S. 254 (1915); Martin v. District of Columbia, 205 U.S. 135 (1907); Adam Schumann Assoclates v. City of New York 27 F.2d 618 (E.D.N.Y. 1928).

86. Nichols v. Kansas City, 291 Mo 690, 237 S.W. 107 (1922) (market value), Gast Realty \& Investment Co. v. Schneider Granite Co., supra, note 85 (front-foot); Gadd v. McGuire, 69 Cal. App. 347, 231 P. 754 (1924) (front-foot); In re Cayuga Heights Village Sewer System, 13 App.Div.2d 1, 211 N.Y.S.2d 873 (1961) (average width of lot parallel with main street frontage); Turner v. Adams, 178 Ark. 67, 100 S.W.2d 41 (1928) (area of parcels).

87. See, e.g., Washington statute discussed in Towers v. City of Tacoma, 151 Wash. 577, 276 P.888, (1929).

88. Wharton v. Oskaloosa, 158 N.W.2d 834 (Iowa 1968); In re St. Raymond Ave., in the City of New York, 175 App.Div. 518, 162 N.Y.S. 185 (1916).

89. 14 McQuillan, The Law of Municipal Corporations, \$38.134 (3rd ed. 1968).

90. Carson v. Sewer Comm'rs, 182 U.S. 398 (1901); Anderson v. City of Frrgo, 64 N.D. 178,250 N.W. 794 (1933); but see Southern Ry. v. C.ity of Richmond, 175 Va. 308, 8 S.E.2d $271(1940)$.

91. State ex rel. Webster Groves Sanitary Dist. v. Smith, 342 Mo. 365, 115 S.W.2d 816, 823 (1938); cf. McCoy v. City of Sistersville, 120 W.Va. 471 , 199 S.E. 260 (1938); and Southern Ry. v. City of Richmond, supra, note 90, holding that the charges were invalid unless imposed in conjunction with actual use; so the true distinguishing feature appears to be that they are ordinarily levied annually on the basis of and in proportion to benefit (determined by frontfoot in Southern Railway and by assessed valuation in Webster Groves).

92. State ex rel. Webster Groves Sanitary Dist. v, Smith, supra note 91.

93. Southern Ry. v. City of Richmond, supra note 90 .

94. Anderson v. City of Fargo, 64 N.D. 178, 250 N.W. 794 (1933).

95. See, e.g., F. M. Hubbell Son \& Co. v. Hammill, 187 Iowa 1083, 175 N.W. 41 (1919), where the entity's refusal of a tender of cash payment on the grounds that it had issued bonds was held to have extinguished the lien.

96. See, e.g., City of El Paso v. West, 102 F.2d 927 (1939); City of Orlando v. Northern Inv. Corp. 116 Fla. 766, 156 So. 890 (1934); Donahue v. Village of LaGrange, 268 Ill. 607,105 N.E. 762 (1914). 
97. See, e.g., Scofield v. City of Council Bluffs, 68 Iowa 695, 28 N.W. 20 (1886); Hubbard Constr. Co. v. City of Orlando, 67 So.2d 675 (Fla. 1953).

98. See, e.g., Cuchia v. Herbert, 133 S.W.2d 140 (Tex. Civ. App. 1939).

99. See, e.g., Hatfield v. School Dis. No. 58, 178 Ark. 260, 10 S.W.2d (1928), involving warrants paid out of a building bond extending over a period of years.

100. Clayton v. Colorado \& S.R. Co., 51 F.2d 977 (10th Cir. 1931); Londoner v. City and County of Denver, 210 U.S. 373(1908); City and County of Denver v. State Inv. Co., 49 Colo. 244, 112 P. 789 (1911); Marshall v. C. S. Young Const. Co., 84 Fla. 11, 113, So. 565 (1927).

101. Saline Branch Drainage Dist. v. Urbana-Champaign Sanitary Dist., 395 Ill. 26, 69 N.E.2d 251 (1946); Grosse Ile Township v. New York Indemnity Co., 260 Mich. 643, 245 N.W. 791 (1932); Garden of Eden Drainage Dist. v. Bartlett Tres. Co., 330 Mo. 554,50 S.W.2d 627 (1932).

102. Ibid.

103. International Typographical Union v. Macomb County, 306 Mich. 562, 11 N.W.2d 242 (1943); Clark v. City of Salem, 61 Ore. 116, 121 P. 416 (1912); Spitcaufsky v. Hatten, 353 Mo. 94, 182 S.W.2d 86 (1944); Carstens \& Earles v. City of Seattle, 84 Wash. 88, 146 P. 381 (1915).

104. John K. \& Catherine S. Mullen Benevolent Corp. v. United States, 290 U.S. 89 (1933); Philadelphia Mortgage \& Trust Co. v. City of Omaha, 63 Neb. 280, 88 N.W. 523 (190 l); L. E. Whitham \& Co. v. Gambrell, 48 S.W.2d 347 (Tex. Civ. App. 1932).

105. Stanley v. Jeffries, 36 Mont. 114, 284 P. 124 (1929).

106. Klemm v. Davenport, 100 Fla. 627, 129 So. 904 (1930).

107. Wicks v. Salt Lake City, 60 Utah 265, 208 P. 538 (1922).

108. Garden City v. Trigg, 57 Kan. 632,47 P. 524 (1897).

109. City of Chicago v. Union Trust Co., 138 Ill. App. 545 (1908).

110. Dunsmuir v. Porter, 7 Cal.2d 269, 60 P.2d 836 (1936).

111. Montgomery v. City and County of Denver, 102 Colo. 427, 80 P.2d 434 (1938); Corey v. City of Ft. Dodge, 133 Iowa 666, 111 N.W. 6 (1907); Hanson v. City of Havre, 112 Mont. 207, 114 P.2d 1053 (1941); Marks v. City of Mandan, 70 N.D. 474, 296, N.W. 39 (1941).

112. County of San Diego v. Hammond, 6 Cal.2d 709, 59 P.2d 478 (1936).

113. County of San Diego v. Hammond, supra note 112; County of Los Angeles v. Jones, 6 Cal.2d 695, 59 P.2d 489 (1936).

114. Graves v. Bliss, 235 Mich. 364, 209 N.W. 142 (1926), cert. denied, 273 U.S. 724 (1926); State ex rel. Bowman v. Board of Comm'rs, 124 Ohio St. 174, 177 N.E. 271 (1931).

115. Hanson v. City of Havre, supra note 111; Marks v. City of Mandan, supra note 111.

116. It is important to note that the property which is the security for or the source of the payment of either the principal or interest on the solar energy bonds need not be the property acquired with the bond proceeds (i.e., the solar energy facilities).

117. But see Rev. Rul, 75-403, 1975-2 C.B. 37. Under the facts of that revenue ruling, 
bonds were issued by a state to provide a source of funds which would be loaned to nonexempt nursing homes for use in the nursing homes' trades or businesses. Although the full faith and credit of the state was pledged to the repayment of the bonds, no assets of or loan payments from the nursing homes were pledged as security for the bonds. Based on these facts, the ruling held that the security interest test was not met, apparently because the debt service schedule on the loans did not coincide with the debt service schedule on the state's proposed bonds, thus indicating, unlike Example 14, supra, that loan repayments would not be needed for bond service.

118. See Fox and Wilson, Industrial Development Bonds, 216 3rd T. M., p. A-14.

119. Such a financing program raises several arbitrage problems, a discussion of which is beyond the scope of this memorandum. Suffice it to say that such a program will undoubtedly be a governmental prograin and the allowable spread between the yield on the issue of solar bonds and the yield nn the loans made to liomenwiners could bc as hight as 1.5\%. See Proposed Treesury Regulations, \$1.103-13(b) (5) (vii).

120. While the Internal Revenue Service has been the author of a number of tenuous arguments, it is highly unlikely that it would argue that the maintenance of a personal residence would be a trade or business because such an argument would conflict with the rationale of $\$ 262$ of the Code, which prohibits any deduction for personal, living or family expenses.

121. See Treasury Regulations, \$1.103-7(c), Examples 6 and 7.

122. Treasury Regulations, $\$ 1.103-8(a)(1)$ (i) indicates that "substantially all" of the proceeds of an issue of governmental obligations are used to provide an exempt facility if $90 \%$ or more of those proceeds are so used.

123. Section 332 of the Revenue Act of 1978, amending \$103(b) of the Internal Revenue Code of 1954, modifies to some degree the "two-county" rule contained in Treasury Regul ations, $\$ 1.103-8(f)(2)(888)$ by providing that bonds used to provide facilities for fumishing of electric energy are tax-exempt if the energy is sold to a public. utility that serves an area no groater than one vily and one contiguous county. 'l'his rule applies to tax years ending after 30 Apr. 68, but only for obligations issued af ter such date.

124. See Rev. Rul. 78-12, 1978-2 I.R.B.11, which held that facilities for the generation and distribution of steam, which would be used to heat certain office buildings in a downtown area, are not facilities for the local furnishing of gas under $\$ 103(\mathrm{~b})(4)(\mathrm{E})$ of the Code or facilities for the furnishing of water under $\$ 103(\mathrm{~b})(4)(\mathrm{G})$ of the Code.

125. Treasury Regulations, $\$ 1.103-10(\mathrm{~b})$ (1) (ii) defines "substantially all" as being at least $90 \%$.

126. Section 103(b) (6) (A) of the Code.

127. Treasury Regulations, \$1.103-10(b).

128. Treasury Regulations, $\$ 1.103-10(d)$.

129. It should be noted that $\$ 331$ of the Revenue Act of 1978 raised the limitation from $\$ 5$ million to $\$ 10$ million. The higher limitation applies to bonds issued after 31 Dec. 78.

130. Section 103(b) (6) (D) (ii) of the Code and Treasury Regulations, \$1.103-10(b) (2).

131. For these purposes, a person is related to a substantial user if: (1) the relationship 
is such that it would result in a disallowance of losses under $\$ \$ 267$ and 707(b) of the Code; or (2) the persons are members of the same controlled group of corporations as defined in $\$ 1563$ of the Code, (except that "more that 50\%" is substituted for "at least 80\%" each place it appears in $\$ 1563(\mathrm{a})$. and the Treasury Regulations thereunder. See \$103(b) (6) (C) of the Code, and Treasury Regulations, \$1.103$10(e)$.

132. Cal. Gov't. Code $\$ 43602$ (1963).

133. Cal. Gov't. Code $\$ 43601$ (1963).

134. Cal. Gov't. Code $\$ 5430$ i (1963).

135. Cal. Gov't. Code $\$ 54309$ as amended (West Supp. 1978).

136. Cal. Gov't. Code $\$ 54309$ (b) as amended (West Supp. 1978).

137. Cal. Gov't. Code \$54309.1(c) as amended (West Supp. 1978).

138. Cal. Gov't. Code $\$ 54310$ as amended (West Supp. 1978).

139. Cal. Gov't. Code $\$ 54309(\mathrm{j})$ as amended (West Supp. 1978).

140. Cal. Gov't. Code $\$ 54310$ (a) as amended (West Supp. 1978).

141. Cal. Gov't. Code $\$ 54309$ (a) as amended (West Supp. 1978).

142. Cal. Gov't. Code $\$ 54309.1$ (b) as amended (West Supp. 1978).

143. Cal. Gov't. Code $\$ 54309$ (a) as amended (West Supp. 1978).

144. Cal. Sts. Hy. Code $\$ 5000$ et seq. (1969).

145. Cal. Sts. \& Hy. Code $\$ 6400$ (1969); Bonds may also be issued under alternate provisions of the Improvement Bond Act of 1915, Cal. Sts. \& Hy. Code $\$ 8500$ et seq. (1969).

146. Cal. Sts. \& Hy. Code $\$ 5101$ as amended (West Supp. 1978).

147. Cal. Sts. \& Hy. Code $\$ 5101(h)$.as amended (West Supp. 1978).

148. Mills v. City of Elsinore 93 C.A. 753, 270 P. 224 (1928).

149. Cal. Sts. \& Hy. Code $\$ 5101(\mathrm{i})$ as amended (West Supp. 1978).

150. Cal. Sts. \& Hy. Code $\$ 5101$ (e) as amended (West Supp. 1978).

151. Cal. Sts. \& Hy. Code $\$ 10000$ et seq. (1969).

152. Cal. Sts. \& Hy. Code $\$ 10100$ (1969).

153. Cal. Sts. \& Hy. Code \$10101 (1969).

154. Cal. Sts. \& Hy. Code $\$ 10100$ (b) (1969).

155. Cal. Sts. \& Hy. Code $\$ 10100(\mathrm{c})$ (1969).

156. Cal. Sts, \& Hy. Code $\$ 10100($ a) (1969).

157. Cal. Sts. \& Hy. Code $\$ 10100$ (1969).

158. Cal. Sts. \& Hy. Code $\$ 10007$ (1969).

159. Cal. Health \& Safety Code, $\$ 37916$ (1973):

160. Cal. Health \& Safety Code, $\$ 37915$ as amended (West Supp. 1978).

161. Cal. Health \& Safety Code, $\$ 37912(h)$ as amended (West Supp. 1978). 
162. Cal. Health \& Safety Code, $\$ 37912(\mathrm{i})$ as amended (West Supp. 1978).

163. Cal. Health \& Safety Code, $\$ 37950$ as amended (West Supp. 1978).

164. Fla. Stat. Ann. \$553.87(West Supp. 1978).

165. Fla. Stat. Ann. $\$ 377.705(2)$ (West Supp. 1978).

166. Fla. Const. Art. $7 \$ 12$ (1968).

167. Fla. Stat. Ann. \$166.111 as amended (West Suppl. 1978).

168. Fla. Stat. Ann. $\$ 166.101$ as amended (West Supp. 1978) revenue bonds to finance a restricted list of "self-liquidating" projects.

169. Fla. Stat. Ann. $\$ 159.01$ et seq. (1972).

170. Fla. Stat. Ann. \$159.08 as amended (West Supp. 1078).

171. Fla. Stat. Ann. $\$ 159.02(1)$ as amended (West Bupp. 1978).

172. Fla. Stat.Ann. \$159.02(9) (1972).

173. Fla. Stat. Ann. \$159.02(15) (1972).

174. Fla. Stat. Ann. \$159.02(24) (1972).

175. Fla. Stat. Ann. \$166.111 as amended (West Supp. 1978).

176. Fla. Const. Art. $7 \$ 10$ (1968, amended 1974).

177. Fla. Stat. Ann. \$159.25 et seq. (1972).

178. Fla. Stat. Ann. \$159.28(7) (1972).

179. Fla. Stat. Ann. \$159.27(5) (West Supp. 1978).

180. Id.

181. Fla. Stat. Ann. $\$ 166.101(5)$ as amended (West Supp. 1978).

182. 111. Ann. Stat. Ch. $961 / 2 \$ 7301$ et seq, (West Supp. 1978).

183. Ill. Ann. Stat. Ch. 96 1/2 $\$ 7302$ (West Supp. 1978).

184. Ill. Ann. Stat. Ch. $120 \$ 501 d-1$ (West Supp. 1978).

185. Ill. Ann. Stat. Ch. 96 1/2 $\$ 7315$ (West Supp. 1978).

186. Ill. Aun. St at. Ch. I $\$ 001($ d)-2(2) (b) (West Supp. 1978) and Ill. Ann. Stat. Ch. 96 $1 / 2 \$ 7303(d)(2)(h)$ (West Supp. 1878).

187. Ill. Const. Art. $7 \$ 6$ (1970).

188. ㅍl. Const. Art. $7 \$ 7$ (1970).

189. Ill. Ann. Stat. Ch. 24 \$8-1-3 (Smith-Hurd, 1961).

190. Ill. Ann. Stat. Ch. $24 \$ 11-117-8$ (Smith-Hurd, 1961).

191. Ill. Ann. Stat. Ch. $24 \$ 11-117-2$ (Smith-Hurd, 1961).

192. IIl. Ann. Stat. Ch. $24 \$ 11-19-4$ as amended (Smith-Hurd Supp. 1978) The statute authorizes municipalities to establish "systems or plants" for the "collection and disposal" of "garbage, refuse, and ashes."

193. Ill. Ann. St at. Ch. $24 \$ 8-1-3$ (Smith-Hurd 1961). 
194. Ill. Ann. Stat. Ch. 24 \$11-118-1 as amended (Smith-Hurd Supp. 1978).

195. Ill. Ann. Stat. Ch. 24 \$11-119-1 as amended (Smith-Hurd Supp. 1978).

196. Ill. Ann. Stat. Ch. 24 \$11-74-1-(1) (Smith-Hurd Supp. 1978).

197. Ill. Ann. Stat. Ch. $24 \$ 11-74-4(2)$ (Smith-Hurd Supp. 1978).

198. Ill. Ann. Stat. Ch. 24 \$11-74-2-(1) (Smith-Hurd Supp. 1978).

199. Ill. Ann. Stat. Ch. 24 \$11-74-2-(1) (Smith-Hurd Supp. 1978).

200. Ill. Const. Art. $7 \$ 6$ (1970) and Ill. Const. Art. $7 \$ 7$ (1970).

201. IIl. Ann. Stat. Ch. $24 \$ 9-3-1$ et seq. (1962).

202. Ill. Ann. Stat. Ch. 24 \$9-3-2 (1962).

203. Il. Ann. Stat. Ch. 24 \$9-2-1 (1962).

204. Ill. Ann. Stat. Ch. 24 \$9-2-119 as amended (West Supp. 1978).

205. Ill. Const. Art. 7, $\$ 6$ (1975) and Ill. Ann. Stat. Ch. 120, $\$ \$ 1301$ et seq. (Smith-Hurd Supp. 1979).

206. Hiken Furniture Co. v. City of Belleville, 53 Ill. App. 2d 306, 368 N.E. 2d 961 . (1977).

207. Ill. Const. Art. 7, \$6 (1970).

208. N.M. Stat. Ann. $\$ 4-37-1$ to $4-37-3$ (1975).

209. N.M. Stat. Anin. \$4-37-2 (1975).

210. N.M. Stat. Ann. \$14-29-5 (1976).

211. N.M. Stat. Ann. \$14-29-5(I) (1976).

212. N.M. Stat. Ann. \$14-29-5(A) (1976).

213. N.M. Stat. Ann. \$14-29-5(B) (1976).

214. N.M. Stat. Ann. \$14-29-5(J) (1976).

215. N.M. Stat. Ann. \$14-30-1(A) (1976).

216. N.M. Stat. Ann. \$14-1-2(H) (1976).

217. N.M. Stat. Ann. \$14-30-1(E) (1976).

218. N.M. Stat. Ann. \$14-1-2(L) (1976).

219. N.M. Stat. Ann. \$14-31-1 et seq. (1976).

220. N.M. Stat. Ann. \$14-31-3(C) (1976).

221. N.M. Stat. Ann. \$14-31-1(B) (1976).

222. N.M. Stat. Ann. \$14-31-1(B)(1) (1976).

223. N.M. Stat. Ann. \$14-32-17 (1976).

224. N.M. Stat. Ann. \$14-32-3 (1976).

225. N.Y. Const. Art. $8 \$ 2$ (1938, as amended 1954).

226. N.Y. Local Fin. $\$ 10.00$ as amended (McKinney, Supp. 1978-1979).

227. N.Y. Local Fin. \$11(a)5 as amended (McKinney, Supp. 1978-1979). 
228. N.Y. Local Fin. $\$ 11$ (a)6 (as amended) (McKinney, Supp. 1977-1978).

229. N.Y. Local Fin. \$11(a)13 (McKinney 1968).

230. N.Y. Local Fin. $\$ 11(a) 11$ as amended (McKinney Supp. 1977-78).

231. N.Y. Local Fin. $\$ 11(a) 58$ (McKinney, 1968).

232. N.Y. Gen. Mun. \$403(d) (McKinney, 1974).

233. N.Y. Gen. Mun. $\$ 401$ (McKinney, 1974).

234. N.Y. Gen. Mun. $\$ 850$ et seq. (McKinney 1974).

235. N.Y. Gen. Mun. $\$ 856$ (1)(a) (McKinney 1974).

236. N.Y. Gen. Mun. \$858(12) and 870 (McKinney 1974).

237. N.Y. Gen. Mun. $\$ 858$ (McKinney Supp. 1978-1979).

238. N.Y. 'Town $\$ 180$ as amended (MeKinney Supp. 1978-1979).

239. N.Y. Local Fin. $\$ 24.00$ (McKinney 1968).

240. N.Y. Town \$198 (3)(a) (McKinney, 1965).

241. Id.

242. N.Y. Town \$198(6) (McKinney, 1965).

243. N.Y. Town $\$ 198(9)$ as amended (McKinney 1978-1979).

244. N.Y. Loc. Fin. Law $\$ 21.00$, (McKinney 1968).

245. N.Y. Priv. Hous. Fin. Law $\$ 402$ (McKinney, 1976) incorporating by reference N.Y. Mult. Dwell. Law \$4(8) and 4(9) (McKinney, 1974).

246. N:Y. Priv. Hous. Fin. Law $\$ 402$ (McKinney 1976). 


\begin{tabular}{|c|c|c|}
\hline $\begin{array}{l}\text { Document Control } \\
\text { Page }\end{array}$ & $\begin{array}{l}\text { 1. SERI Report No. } \\
\text { TR-434-191 }\end{array}$ & 3. Recipient's Accession No: \\
\hline \multirow{2}{*}{\multicolumn{2}{|c|}{$\begin{array}{l}\text { 4. Title and Subtitle } \\
\text { Municipal Bond Financing of Solar Energy Facilities }\end{array}$}} & $\begin{array}{l}\text { 5. Publication Date } \\
\text { December } 1979\end{array}$ \\
\hline & & 6. \\
\hline \multicolumn{2}{|c|}{$\begin{array}{l}\text { 7. Author(s) } \\
\text { Sharon Stanton White }\end{array}$} & 8. Performing Organization Rept. No. \\
\hline \multirow{3}{*}{\multicolumn{2}{|c|}{$\begin{array}{l}\text { 9. Pertorming Organization Name and Address } \\
\text { Solar Energy Research Institute } \\
1617 \text { Cole Blvd. } \\
\text { Golden, Colo. } 80401\end{array}$}} & $\begin{array}{l}\text { 10. Project/Task/Work Unit No. } \\
\text { Task \#6721.40 }\end{array}$ \\
\hline & & $\begin{array}{l}\text { 11. Contract (C) or Grant (G) No. } \\
\text { (C) }\end{array}$ \\
\hline & & (G) \\
\hline \multirow{2}{*}{\multicolumn{2}{|c|}{ 12. Sponsoring Organization Name and Address }} & $\begin{array}{l}\text { 13. Type of Report \& Period Covered } \\
\text { Technical Report }\end{array}$ \\
\hline & & 14. \\
\hline
\end{tabular}

15. Supplementary Notes

16. Abstract (Limit: 200 words) This report examines the application of the laws of municipal bond financing to solar facilities and is based upon the assumption that the solar facilities proposed to be financed are both technically feasible and economically beneficial. The introduction outlines the type of facilities under consideration. Section 2.0 discusses the general legal principles of municipal securities financing. The effect of recent decisions applying antitrust liability to municipal corporations is also discussed. Section 2.0 then turns to five specific types of municipal bonds and explains the nature of such bonds. The application of Section. 1.03 of the Internal Revenue Code of 1954, as amended, to the issuance of municipal bonds for solar facility financing is examined also. Section 3.0 examines five bond laws of five representative states and discusses whether the eight types of solar facilities under consideration could be financed under such law. Section 4.0 illustrates the application of the general legal principle discussed in Section 1.0 and 2.0. It sets forth three hypothetical siutations and discusses common legal issues to be confronted by city officials in proposing such financing. These issues will be raised in most financings, but the purpose of Section 4.0 is to examine the common context in which they are raised. The report concludes that if it can be shown that the purpose of the solar facilities to be financed is to benefit the public, all legal obstacles to the use of municipal financing of solar facilities can be substantially overcome.

17. Document Analysis

a. Descriptors Municipal Bonds ; Financing ; Solar Energy Conversion Systems; Wind Energy Conversion Systems; Biomass Conversion Systems ; Ocean Thermal Energy Conversion Systems ; Solar Heating Systems; Solar Cooling Systems ; Residential Sector ; Commercial

b. Identiflers/Open-Ended Terms Sector; Agricultural Process Heat Systems ; Industrial

Process Heat Systems; Solar Thermal Conversion Systems;

Photovoltaic Conversion Systems ; Solar Power Satellites ;

c. UC Categories Legal Aspects ; California ; Florida ; Illinois ; New Mexico ; New York ; Legislation; Internal Revenue Code of $59,60,61,62,63,64$ 1954 (Ammended) Section 103

18. Availability Statement

National Technical Information Service II.S. Dept, of Commerce

5285 Port Royal Road, Springfield, Va. 22161 